\title{
ARPP-21, a Cyclic AMP-Regulated Phosphoprotein Enriched in Dopamine-Innervated Brain Regions. I. Purification and Characterization of the Protein from Bovine Caudate Nucleus
}

\author{
Hugh C. Hemmings, Jr., ${ }^{a}$ and Paul Greengard \\ Laboratory of Molecular and Cellular Neuroscience, The Rockefeller University, New York, New York 10021
}

ARPP-21 (cAMP-regulated phosphoprotein, $M_{r}=21,000$ as determined by SDS/PAGE) is a major cytosolic substrate for CAMP-stimulated protein phosphorylation in dopamine-innervated regions of rat CNS (Walaas et al., 1983c). This acidic phosphoprotein has now been identified in bovine caudate nucleus cytosol and purified to homogeneity from this source. The purification procedure involved diethylaminoethyl-cellulose chromatography, ammonium sulfate fractionation, phenyl-Sepharose CL-4B chromatography, and fast protein liquid chromatography using Mono $Q$ anion-exchange resin. Two isoforms of ARPP-21 (ARPP-21A and ARPP-21B) were obtained, which were present in approximately equal amounts in the starting material. ARPP-21A was purified 2610 -fold with a final yield of $20 \%$ and ARPP. $21 B$ was purified 2940 -fold with a final yield of $21 \%$. The purified preparations of both isoforms were judged to be homogenous by SDS/PAGE. ARPP-21A and ARPP-21B yielded identical 2-dimensional thin-layer tryptic phosphopeptide maps, identical amino acid compositions and closely related, but distinct, reverse-phase high-pressure liquid chromatograms of tryptic digests. The amino acid composition of ARPP-21 showed a high content of glutamic acid/glutamine, and no methionine, tryptophan, tyrosine, phenylalanine, or histidine. ARPP-21 was stable to heat denaturation and to $50 \%(\mathrm{vol} / \mathrm{vol})$ ethanol treatment and was partially soluble at pH 2. The $M$, determined for ARPP-21 by SDS/PAGE was 21,000. The Stokes radius of ARPP-21 was $26.3 \AA$, and the sedimentation coefficient of ARPP-21 was $1.3 \mathrm{~S}$; these values yield a calculated molecular mass of $13,700 \mathrm{Da}$ and a frictional ratio of 1.7, indicative of an elongated tertiary structure. ARPP-21 was an excellent substrate for CAMP-dependent protein kinase and was either not phosphorylated or only poorly phosphorylated by cGMP-dependent protein kinase, calcium/calmodulin-dependent protein kinase I, calcium/calmodulin-dependent protein kinase II, casein kinase II, or protein kinase $C$. The purified catalytic subunit of CAMP.

\footnotetext{
Received Feb. 26, 1988; revised July 15, 1988; accepted July 18, 1988.

This work was supported by United States Public Health Service Grant MH40899. A preliminary report of some of this research was presented at the 16th Annual Meeting of the Society for Neuroscience, Washington, D.C., 1986 (Hemmings et al., 1986b). We wish to thank Kenneth R. Williams and Mary B. LoPresti of the Department of Molecular Biophysics and Biochemistry of the Yale School of Medicine for performing the amino acid analyses and HPLC peptide mapping. The second paper of this series describes the immunocytochemical localization of ARPP-21 in rat brain (Ouimet et al., 1989).

Correspondence should be addressed to Paul Greengard, Box 296, The Rockefeller University, 1230 York Avenue, New York, NY 10021.

a Present address: Department of Anaesthesia, Massachusetts General Hospital, Boston, MA 02114.

Copyright (C) 1989 Society for Neuroscience $0270-6474 / 89 / 030851-14 \$ 02.00 / 0$
}

dependent protein kinase catalyzed the incorporation of $\mathbf{1 . 2}$ mol phosphate/mol purified ARPP-21. Phosphorylation occurred exclusively on seryl residues. Phospho-ARPP-21 was dephosphorylated effectively by protein phosphatase-1 or $-2 \mathrm{~A}$, but not by protein phosphatase-2B or $-2 \mathrm{C}$. Rabbit polyclonal and mouse monoclonal antibodies were prepared to purified ARPP-21. These antibodies specifically immunoprecipitated ARPP-21, which was found to be highly enriched in the caudate nucleus and putamen of monkey brain. In an accompanying paper, we report the use of antibodies to ARPP-21 for the immunocytochemical localization of ARPP21 in rat brain (Ouimet et al., 1989). The available evidence suggests that ARPP-21 is a CAMP-regulated phosphoprotein (ARPP) highly enriched in dopamine-innervated brain regions and may therefore play a role as an intracellular messenger in mediating some of the effects of dopamine and/ or other neurotransmitters acting via CAMP in the basal ganglia.

Protein phosphorylation is a molecular mechanism by which many extracellular signals, including various neurotransmitters, appear to produce specific physiological effects in the nervous system (for reviews, see Greengard, 1978; Nestler and Greengard, 1984; Nairn et al., 1985; Hemmings et al., 1986a, 1987a). Certain of the physiological effects of dopamine appear to be mediated by the second-messenger cAMP (Kebabian et al., 1972; Kebabian and Calne, 1979; Stoof and Kebabian, 1984). The stimulation of adenylate cyclase by dopamine acting at D-1 dopamine receptors results in the activation of cAMP-dependent protein kinase and the resultant phosphorylation of specific substrate proteins (for review, see Hemmings et al., 1987b). The identification, purification, and characterization of these substrate proteins provides an approach to learning more about the biochemical mechanisms involved in the responses of cells that possess D-1 dopamine receptors to stimulation by dopamine.

A distinct subset of substrates for cAMP-dependent protein kinase, with highly restricted regional distributions similar to the distribution of axon terminals of the mesencephalic dopaminergic neurons, has been identified in rat CNS (Walaas et al., $1983 \mathrm{~h}, \mathrm{c}$ ). At least 7 of these substrates (soluble phosphoproteins of $M_{r}=98,000 ; 96,000 ; 81,000 ; 40,000 ; 32,000 ;$ and 21,000 ; and a particulate phosphoprotein of $M_{r}=39,000$ ) were found to be highly enriched in the forebrain basal ganglia, brain regions that are heavily innervated by dopaminergic neurons (for reviews, see Lindvall and Björklund, 1978; Moore and Bloom, 1978; Björklund and Lindvall, 1984) and that contain relatively high amounts of dopamine-sensitive adenylate cyclase activity (for review, see Miller and McDermed, 1979) and of D-1 do- 
pamine receptors (Boyson et al., 1986; Dawson et al., 1986; Dubois et al., 1986; Savasta et al., 1986). Furthermore, the state of phosphorylation of the soluble phosphoprotein of $M_{r}=32,000$ (known as DARPP-32') has been found to be regulated by dopamine and by the cAMP analog 8-bromo-cAMP in intact cells of the rat caudatoputamen (Walaas et al., 1983a; Walaas and Greengard, 1984). It appears likely that DARPP-32 and other substrates for CAMP-dependent protein kinasc that are conccntrated within cells that possess D-1 dopamine receptors are involved in mediating certain of the physiological effects observed following stimulation by dopamine.

The purification and biochemical characterization of DARPP32 from bovine caudate nucleus has been reported (Hemmings et al., 1984a-d; Hemmings and Greengard, 1986; Williams et al., 1986). DARPP-32 is a potent inhibitor, in its phosphorylated form, of the broad-specificity enzyme protein phosphatase-1. This effect may be an important component of the biochemical mechanisms involved in mediating some of the effects of dopamine acting on dopaminoceptive cells (Hemmings et al., 1984a, 1987c). ARPP-21, like DARPP-32, was found by Walaas et al. (1983c) to exhibit a highly restricted regional distribution in rat $\mathrm{CNS}$ corresponding to the distributions of dopaminecontaining axon terminals, dopamine-sensitive adenylate cyclase activity and D-1 dopamine receptors. Recently, the state of phosphorylation of ARPP-21, like that of DARPP-32, has been found to be regulated by 8 -bromo-cAMP in intact neurons (Girault et al., 1987, 1988; Shalaby et al., 1987). We now report the purification of ARPP-21 (c $A$ MP-regulated phosphoprotein, $M_{r}=21,000$ ). The purified preparation of bovine ARPP-21 has been biochemically characterized and used to prepare both rabbit antiserum and mouse monoclonal antibodies. These antibodies have been employed to determine the regional and cellular distribution of ARPP-21 in rat CNS by immunocytochemical methods, as described in the accompanying paper (Ouimet et al., 1989).

\section{Materials and Methods}

Materials. Materials were obtained from the following sources: Tris, glycine, ATP, BSA (fraction V powder), methylene bisacrylamide, 2-mercaptoethanol, Coomassie brilliant blue R250, 8-bromo-cAMP, and EGTA from Sigma Chemical Co.; deoxycholic acid (sodium salt), HEPES, and PMSF from Calbiochem-Behring; DTT from Boehringer Mannheim Biochemicals; leupeptin and pepstatin A from Chemicon (Los Angeles); ammonium sulfate from Bethesda Research Laboratories; triethanolamine, ammonium bicarbonate, trichloroacetic acid, and ethylene glycol from Fisher Scientific Co.; acrylamide and thin-layer cellulose sheets (type 13254) from Eastman Co.; DEAE-cellulose from Whatman, Ltd.; phenyl-Sepharose CL-4B, Mono-Q anion-exchange FPLC resin, Sephadex G-25 (fine) and DE Sephacel from Pharmacia; Liquiscint scintillation fluid from National Diagnostics; Bio-Rad Protein Assay Dye Reagent from Bio-Rad Laboratories; ampholytes from $\mathrm{LKB}$; and $\gamma-{ }^{32} \mathrm{P}-\mathrm{ATP}$, iodo- ${ }^{14} \mathrm{C}$-acetic acid, and ${ }^{125} \mathrm{I}$-Bolton Hunter reagent from New England Nuclear. All other chemicals used were of reagent grade.

Fresh calf brains were obtained from a local slaughterhouse and either transported to the laboratory on ice or dissected and transported to the laboratory in liquid nitrogen. The caudate nuclei were stored frozen at $-70^{\circ} \mathrm{C}$ for up to 1 year before use. Male Sprague-Dawley rats $(150-200$ gm body weight) were obtained from Charles River Laboratories. Frozen brain tissue from Macacca mulatta was a gift of Dr. Tamas Bartfai.

' Abbreviations used: ARPP-21, c $A$ MP-regulated $p$ hosphoprotein, $M_{r}=21,000$ as determined by SDS/PAGE; DARPP-32, dopamine- and $c A$ MP-regulated $p$ hosphoprotein, $M_{r}=32,000$ as determined by SDS/PAGE; DTT, dithiothreitol: FPLC, fast protein liquid chromatography; HPLC, high performance liquid chromatography; IEF, isoelectric focusing; PMSF, phenylmethylsulfonyl fiuoride.
Enzymes. The catalytic subunit of cAMP-dependent protein kinase was purified from bovine heart as described previously (Kaczmarek et al., 1980). cGMP-dependent protein kinase was purified from bovine lung as described previously (Walter et al., 1980). Calcium/calmodulindependent protein kinase I was purified from bovine brain (Nairn and Greengard, 1987) and was a gift of A. C. Nairn of The Rockefeller University. Calcium/calmodulin-dependent protein kinase II was purified from rat brain (McGuinness et al., 1985) and was a gift of Y. Lai of The Rockefeller University. Protein kinase C was purified from bovine brain (Albert et al., 1984) and was a gift of K. A. Albert of The Rockefeller University. Casein kinase II was purified from rabbit reticulocytes (Hathaway and Traugh, 1983) and was a gift of J. Traugh of the University of California at Riverside. TPCK-trypsin was obtained from Cooper Biomedical (Malvern, PA).

Buffers. All solutions were made with distilled water which was further purified using a Barnstead Nanopure filtration system. Buffer $\mathrm{pH}$ values refer to measurements made at $4^{\circ} \mathrm{C}$. Buffer A consisted of $10 \mathrm{~mm}$ potassium phosphatc (pH 7.5), 1 mM EDTA, 0.5 mм EGTA, 1 mм DTT, $0.2 \mathrm{mM}$ PMSF, $0.1 \%$ (vol/vol) isopropanol (necessary as a solvent for PMSF), $5 \mu \mathrm{g} / \mathrm{ml}$ pepstatin A, and $10 \mu \mathrm{g} / \mathrm{ml}$ leupeptin. Buffer B consisted of $10 \mathrm{~mm}$ Tris- $\mathrm{HCl}$ (pH 8.0), $1 \mathrm{~mm}$ EDTA, $0.5 \mathrm{~mm}$ EGTA, $1 \mathrm{~mm}$ DTT, $0.2 \mathrm{~mm}$ PMSF, $0.1 \%$ (vol/vol) isopropanol, and $10 \mu \mathrm{g} / \mathrm{ml}$ leupeptin. Buffer $\mathrm{C}$ consisted of buffer B containing $45 \%$ saturated (at $0^{\circ} \mathrm{C}$ ) ammonium sulfate $(0.258 \mathrm{gm} / \mathrm{ml})$. Buffer D consisted of buffer B containing $50 \%$ (vol/vol) ethylene glycol. Buffer E consisted of $20 \mathrm{~mm}$ triethanolamine- $\mathrm{HCl}(\mathrm{pH} 7.5)$ and $1 \mathrm{~mm}$ DTT.

$S D S / P A G E$. SDS/PAGE was carried out using slab gels prepared from $11.5 \%$ (wt/vol) acrylamide and $0.31 \%$ (wt/vol) methylene bisacrylamide in the presence of 2-mercaptoethanol by the method of Laemmli (1970). Gels were stained with $0.1 \%$ (wt/vol) Coomassie brilliant blue R250 in $50 \%$ (vol $/ \mathrm{vol})$ methanol $/ 10 \%(\mathrm{vol} / \mathrm{vol})$ acetic acid and destained in $25 \%$ (vol $/ \mathrm{vol})$ methanol $/ 10 \%$ ( vol $/ \mathrm{vol}$ ) acetic acid. Molccular-weight standards, gel drying, and autoradiography were performed as described previously (Hemmings et al., 1984b).

Two-dimensional PAGE with isoelectric focusing (IEF) in the first dimension and SDS/PAGE in the second dimension was performed as described by O'Farrell (1977) with the following modifications. Samples were phosphorylated as described below, and the reactions were terminated by the addition of trichloroacetic acid to a final concentration of $10 \%$ (wt $/ \mathrm{vol})$. The precipitated proteins were recovered by centrifugation at $12,400 \times g$ for $10 \mathrm{~min}$ in a Beckman Microfuge 12. The precipitate was washed 3 times with acetone at $-20^{\circ} \mathrm{C}$, dissolved in lysis buffer, and subjected to IEF in tube gels. The ampholytes used were $150 \mu \mathrm{l}$ of $\mathrm{pH} \mathrm{3-10}$ and $100 \mu \mathrm{l}$ of $\mathrm{pH} 5-7$. Following IEF, the tube gels were applied to slab gels ( $11.5 \%$ acrylamide) and separated in a second dimension as described above.

Endogenous phosphorylation of crude cytosolic extracts. Fresh tissue samples were homogenized in $10 \mathrm{vol}(\mathrm{ml} / \mathrm{gm})$ of buffer at $4^{\circ} \mathrm{C}$ with a Teflon-glass homogenizer using 20 up-and-down strokes at $2100 \mathrm{rpm}$. The homogenates were centrifuged in a Beckman L3-50 ultracentrifuge using an $\mathrm{SW} 50.1$ rotor at $100,000 \times g$ for $1 \mathrm{hr}$ at $4^{\circ} \mathrm{C}$. The supernatants were dialyzed against buffer $\mathrm{A}$ for $2 \mathrm{hr}$ at $4^{\circ} \mathrm{C}$. Aliquots were phosphorylated by endogenous protein kinase in a reaction mixture (final volume, $0.1 \mathrm{ml}$ ) containing $50 \mathrm{~mm}$ sodium HEPES ( $\mathrm{pH} 7.4$ ), $1 \mathrm{~mm}$ EGTA, 10 mM magnesium acetate, and $2 \mu \mathrm{M} \gamma-{ }^{32} \mathrm{P}-\mathrm{ATP}$, in the absence or presence of $10 \mu \mathrm{M}$ 8-bromo-cAMP. The phosphorylation reactions were carried out at $30^{\circ} \mathrm{C}$ for $1 \mathrm{~min}$ and terminated by the addition of "SDS-stop solution" to yield the following final concentrations: $50 \mathrm{~mm}$ Tris- $\mathrm{HCl}$ (pH 7.4), 10\% (vol/vol) glycerol, 2\% (vol/vol) 2-mercaptoethanol, 1\% (wt/vol) SDS, and $0.04 \mathrm{mg} / \mathrm{ml}$ pyronin $Y$. The phosphorylated samples were then heated to $95^{\circ} \mathrm{C}$ for $2 \mathrm{~min}$ and subjected to SDS/PAGE, followed by autoradiography of the dried gels.

Phosphorylation assay for $A R P P-21$. ARPP-21 was assayed by its ability to accept the $\gamma$-phosphoryl group from $\gamma-{ }^{32} \mathrm{P}$-ATP in a reaction catalyzed by the catalytic subunit of cAMP-dependent protein kinase. Samples for the assay were dialyzed against buffer A for $2 \mathrm{hr}$ prior to phosphorylation. The reaction mixture (final volume, $0.1 \mathrm{ml}$ ) contained $50 \mathrm{~mm}$ sodium HEPES (pH 7.4), 1 mм EGTA, $10 \mathrm{~mm}$ magnesium acetate, $2-4 \mu \mathrm{g} / \mathrm{ml}$ of the catalytic subunit of cAMP-dependent protein kinase, and $50 \mu \mathrm{M} \gamma^{-32}$ P-ATP $(200-1000 \mathrm{cpm} / \mathrm{pmol})$. The reaction mixtures, containing all components except the catalytic subunit of cAMPdependent protein kinase and $\gamma^{32} \mathrm{P}$-ATP, were heated at $95^{\circ} \mathrm{C}$ for $2 \mathrm{~min}$ prior to phosphorylation to eliminate endogenous protein kinase and phosphoprotein phosphatase activities. The phosphorylation reactions were carried out for $60 \mathrm{~min}$ (unless indicated otherwise) at $30^{\circ} \mathrm{C}$ and 
were terminated by the addition of "SDS-stop solution." The phosphorylated samples were then heated at $95^{\circ} \mathrm{C}$ for $2 \mathrm{~min}$ and subjected to SDS/PAGE, followed by autoradiography of the dried gels. Phosphorylated bands corresponding to the $M_{r}=21,000$ phosphoprotein were cut out of the gel and the amount of ${ }^{32} \mathrm{P}$-radioactivity incorporated was determined by liquid scintillation spectrometry in $3 \mathrm{ml}$ of Liquiscint. The "substrate activity" of ARPP- 21 is defined as the picomoles of ${ }^{32} \mathrm{P}$-phosphate incorporated into the $M_{r}=21,000$ band using this assay.

Two-dimensional thin-layer phosphopeptide mapping. Gel pieces containing phosphorylated ARPP-21 were subjected to proteolysis within the gel by a method described previously (Hemmings et al., 1984c) except that the protease used for digestion was $75 \mu \mathrm{g} / \mathrm{ml}$ TPCK-trypsin. Electrophoresis and chromatography of the tryptic digests were performed as described previously (Hemmings et al., 1984c).

Analytical HPLC peptide mapping. ARPP-21A and ARPP-21B were reduced, $\mathrm{S}-{ }^{14} \mathrm{C}$-carboxymethylated and digested with TPCK-trypsin by a method described previously (Williams et al., 1986). The resulting tryptic peptides were analyzed by reverse-phase HPLC as described (Williams et al., 1986), except that a Vydak C-4 column was used. Peptides were eluted with linear gradients containing increasing concentrations of solvent B $[0.05 \%$ ( vol $/ \mathrm{vol}$ ) trifluoroacetic acid and $80 \%$ ( $\mathrm{vol} / \mathrm{vol})$ acetonitrile] into solvent A [0.05\% (vol/vol) trifluoroacetic acid] as follows: $0-90 \mathrm{~min}(0-37.5 \% \mathrm{~B}), 90-135 \mathrm{~min}(37.5-75 \% \mathrm{~B})$.

Dephosphoryation of phosphorylated ARPP-2I by various purified protein phosphatases. Purified protein phosphatase-1, $-2 \mathrm{~A},-2 \mathrm{~B}$, and $-2 \mathrm{C}$ and phosphorylated phosphorylase kinase were prepared, and dephosphorylation assays performed as described by Hemmings et al. (1984a). Purified ARPP-21 (A and B) was phosphorylated to a stoichiometry of $0.8-1.0 \mathrm{~mol}{ }^{32} \mathrm{P} / \mathrm{mol}$ protein and purified from unreacted $\gamma^{-32} \mathrm{P}-\mathrm{ATP}$ by dialysis and ion-exchange chromatography using DE-Sephacel.

Radioiodination of ARPP-21. Purified ARPP-21 (5 $\mu \mathrm{g})$ was radioiodinated by the method of Bolton and Hunter (1973) using $2 \mathrm{mCi}$ of diiodinated ${ }^{125} \mathrm{I}$-Bolton-Hunter reagent. Iodination by the chloramine $\mathrm{T}$ method was ineffective due to the absence of tyrosine residues in ARPP-21 (see below). ${ }^{125}$ I-labeled ARPP-21 was separated from the reaction mixture by gel filtration through Sephadex G-25 (fine) as described (Hemmings and Greengard, 1986) and stored at $-70^{\circ} \mathrm{C}$ in small aliquots. This procedure resulted in a preparation of ${ }^{125} \mathrm{I}$-labeled ARPP21 in which $85-100 \%$ of the total ${ }^{125}$ I radioactivity was contained in intact ARPP-21 as determined by SDS/PAGE.

Antibody detection assay. Rabbit and mouse sera, hybridoma culture supernatants and ascites fluid were analyzed for anti-ARPP-21 antibodies by their ability to precipitate ${ }^{125}$ I-labeled ARPP-21 using fixed Protein A-bearing Staphylococcus aureus cells (Pansorbin, CalbiochemBehring) as an immunoadsorbent as described previously for DARPP32 (Hemmings and Greengard, 1986), with the following modification: rabbit anti-mouse antiserum (Cappell Laboratories) was added to the immunoprecipitation assay as a second antibody at a final dilution of 1:500.

Preparation of rabbit anti-ARPP-21 antibodies. Antiserum to ARPP21 was raised in 3 female New Zealand white rabbits $(1.5-2 \mathrm{~kg})$ as described previously for DARPP-32 (Hemmings and Greengard, 1986), except that $100 \mu \mathrm{g}$ per rabbit of purified ARPP-21 (A and B) emulsified in Freund's complete adjuvant was injected on day 0 , and $50 \mu \mathrm{g}$ per rabbit of purified ARPP-21 in Freund's incomplete adjuvant was injected on days 14 and 28 . The rabbits were bled on day 38 , and the antiserum was collected and stored at $-70^{\circ} \mathrm{C}$ in small aliquots.

Preparation of mouse anti-ARPP-21 monoclonal antibodies. Monoclonal antibodies were produced in BALB/c mice essentially by the method of Köhler and Milstein (1975) as described previously for DARPP-32 (Hemmings and Greengard, 1986). This procedure yielded 10 stable anti-ARPP-21 antibody-producing hybrid cell lines, from 2 separate cell fusions, designated 21-1A, 21-3D, 21-4B, 21-6A, 21-7A, $21-7 \mathrm{G}, 21-7 \mathrm{~N}, 21-14.1,21-14.3,21-14.5$. Ascites was induced in pristane-primed BALB/c mice using each cell line, and the $\gamma$-globulin fractions were obtained by precipitation of the ascitic fluid with $45 \%$ saturated ammonium sulfate at $4^{\circ} \mathrm{C}$. The precipitated proteins were dialyzed into PBS and stored at $70^{\circ} \mathrm{C}$ in small aliquots.

Miscellaneous methods. Determination of Stokes radius by gel filtration and of sedimentation coefficient by linear sucrose density gradient ultracentrifugation (Hemmings et al., 1984b), identification of phosphorylated amino acids (Hemmings et al., 1984c), amino acid analysis (Hemmings et al., 1984d), and protein determinations using a modification (Peterson, 1977) of the method of Lowry et al. (1951) were carried

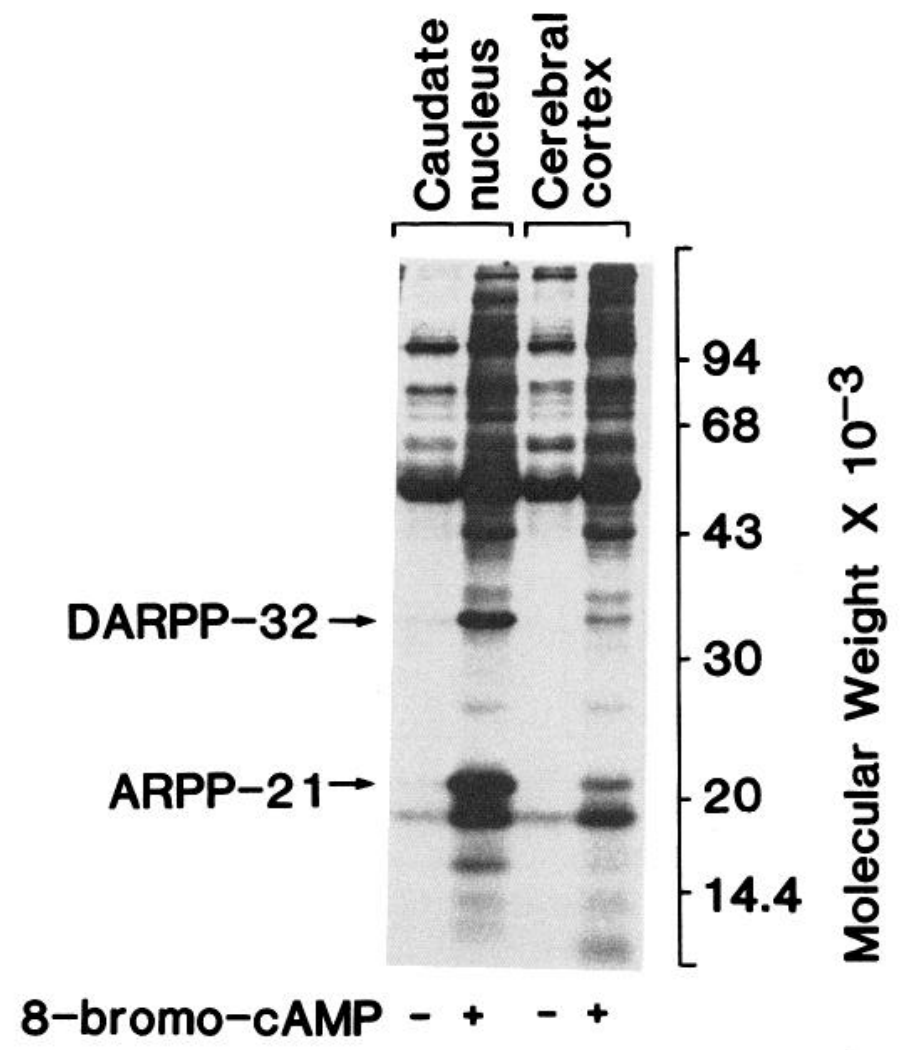

Figure 1. 8-bromo-cAMP-stimulated endogenous phosphorylation of cytosolic extracts prepared from bovine caudate nucleus or cerebral cortex analyzed by SDS/PAGE. Samples containing $40 \mu \mathrm{g}$ protein, determined by the method of Bradford (1976), were subjected to phosphorylation for $60 \mathrm{sec}$ in the absence or presence of $10 \mu \mathrm{M} 8$-bromocAMP, as indicated, and analyzed by SDS/PAGE ( $11.5 \%$ acrylamide). An autoradiogram of the dried gel is shown. Two prominent low-M, phosphoproteins, which are more concentrated in caudate nucleus than in cerebral cortex, are labeled (DARPP-32 and $A R P P-21)$.

out as described previously. Protein determinations using the Coomassie blue-dye-binding assay were performed as described by Bradford (1976) using the Bio-Rad Protein Assay Dye Reagent. Initial rates of phosphorylation of ARPP-21 by various purified preparations of protein kinases were determined by a method described previously (Hemmings et al., 1984c) using modifications in the reaction mixtures necessary for maximal activation of each protein kinase as described in the references cited above for each protein kinase. Subcellular fractionation of bovine caudate nucleus homogenates by differential centrifugation was carried out by a modification of the method of Whittaker and Barker (1972) as described by Walaas and Greengard (1984).

\section{Results}

\section{ARPP-21 in bovine brain}

Identification of ARPP-21 in bovine caudate nucleus. When crude cytosolic fractions prepared from bovine caudate nucleus homogenates were subjected to endogenous phosphorylation stimulated by 8 -bromo-cAMP, a prominent phosphoprotein with an apparent $M_{r}=21,000$ was observed (Fig. 1). This phosphoprotein was named ARPP-21, for c $A \mathrm{MP}$-regulated phosphoprotein of $M_{r}=21,000$ as determined by SDS/PAGE. ARPP21 was present at a much higher concentration in caudate nucleus than in cerebral cortex as determined by the endogenous phosphorylation assay (Fig. 1). Analysis of the subcellular localization of ARPP-21 in bovine caudate nucleus by differential 

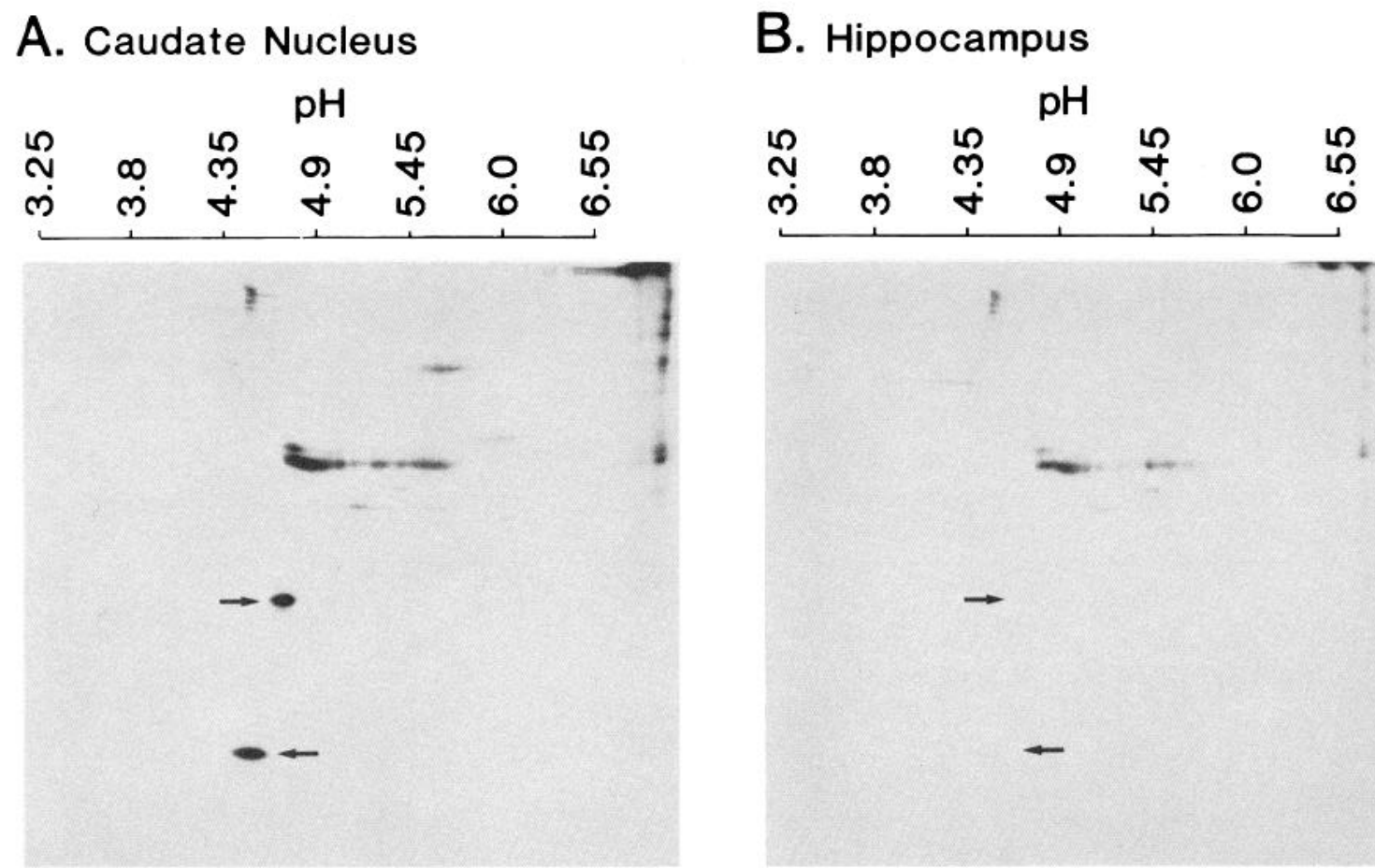

Figure 2. Endogenous phosphorylation of cytosolic extracts prepared from bovine caudate nucleus or hippocampus analyzed by 2-dimensional PAGE. Samples containing $100 \mu \mathrm{g}$ protein, determined by the method of Bradford (1976), were subjected to phosphorylation for 60 sec in the presence of $10 \mu \mathrm{M}$ 8-bromo-cAMP. The samples were analyzed by IEF in the horizontal dimension followed by SDS/PAGE (11.5\% acrylamide) in the vertical dimension. Autoradiograms of the dried gels are shown. Two prominent acidic phosphoproteins are more highly concentrated in caudate nucleus than in hippocampus, with apparent $M_{r}$ values of 32,000 (corresponding to DARPP-32 and indicated by the arrow pointing right) and 21,000 (corresponding to ARPP-21 and indicated by the arrow pointing left).

centrifugation revealed that the $M_{r}=21,000$ phosphoprotein was highly enriched in the soluble fraction (data not shown).

The existence of a soluble phosphoprotein with a $M_{r}=21,000$ that is highly concentrated in the caudatoputamen of rat CNS was reported previously (Walaas et al., 1983c). The distribution of this phosphoprotein in rat brain is similar to that of DARPP32 (Hemmings et al., 1984b), a dopamine- and cAMP-regulated phosphoprotein with an apparent $M_{r}=32,000$, which is also evident in Figure 1. Two other low molecular weight phosphoproteins of $M_{r}=19,000$ and $M_{r}=16,000$ are also seen to be enriched in the caudate nucleus (Fig. 1, Girault et al., 1987).

Analysis of ARPP-21 by 2-dimensional PAGE. Further analysis by 2-dimensional PAGE of ARPP-21 phosphorylated in bovine brain cytosolic fractions by the addition of 8-bromocAMP is shown in Figure 2. Two prominent 8-bromo-cAMPstimulated phosphoproteins, which appeared to be highly concentrated in caudate nucleus, correspond to ARPP-21 and DARPP-32. Both phosphoproteins were present at much lower concentrations in the hippocampus (Fig. $2 B$ ). The isoelectric point of phosphorylated ARPP-21 determined using this technique was 4.5 and that of phosphorylated DARPP-32 was 4.6 (Hemmings et al., 1984b).

Analysis of ARPP-21 by 2-dimensional thin-layer phosphopeptide mapping. The 8-bromo-cAMP-regulated $M_{r}=21,000$ phosphoprotein (ARPP-21) present in endogenously phosphorylated bovine caudate nucleus cytosol (Fig. 1) was compared with the $M_{r}=21,000$ phosphoprotein previously observed in rat caudatoputamen cytosol (Walaas and Greengard, 1984) by 2-dimensional thin-layer phosphopeptide mapping of tryptic digests. Both phosphoproteins yielded identical peptide maps consisting of a single, highly basic and hydrophilic phospho- peptide (Fig. $3 A$ ), indicating that these 2 phosphoproteins represent the homologous forms of rat and bovine ARPP-21. Based upon these experiments, which demonstrated the homology of rat and bovine ARPP-21, bovine caudate nucleus cytosol was chosen as the starting material for the large-scale purification of ARPP-21.

\section{Purification of bovine ARPP-21}

All purification steps were performed at $0-4^{\circ} \mathrm{C}$ unless indicated otherwise. Centrifugations were carried out using Sorvall RC 2-B centrifuges.

Step 1: homogenization and centrifugation. Frozen bovine caudate nuclei $(500 \mathrm{gm})$ at $-70^{\circ} \mathrm{C}$ were equilibrated to $-20^{\circ} \mathrm{C}$ and thawed in 1 liter of buffer $\mathrm{A}$ at room temperature. An additional liter of buffer $\mathrm{A}$ at $4^{\circ} \mathrm{C}$ was added, and the tissue was homogenized twice for 1 min using a Brinkman Polytron homogenizer at setting 5 . The homogenate was centrifuged at 1500 $\times g$ for $20 \mathrm{~min}$ in a GS-3 rotor. The supernatant was decanted through glass wool. The pellet was rehomogenized in 1 liter of buffer $\mathrm{A}$ at $4^{\circ} \mathrm{C}$ for $1 \mathrm{~min}$ and centrifuged at $1500 \times g$ for 20 min in a GS-3 rotor. The second supernatant was decanted through glass wool and combined with the first supernatant. The combined supernatants were then centrifuged at $27,000 \times g$ for $4 \mathrm{hr}$ in a GSA rotor. The supernatant was used for the purification of ARPP-21 (below) and other soluble striatal phosphoproteins (A. Horiuchi, A. C. Nairn, H. C. Hemmings, Jr. and P. Greengard, unpublished observations).

Step 2: DEAE-cellulose chromatography. The clear, light red supernatant was adjusted to $\mathrm{pH} 7.5$ with $1 \mathrm{~N} \mathrm{KOH}$ and diluted to 2.5 liters with buffer A (final conductivity, about $240 \mu \mathrm{S}$ ). The supernatant was then loaded at a flow rate of $4 \mathrm{ml} / \mathrm{min}$ 
A.

RAT ARPP-21

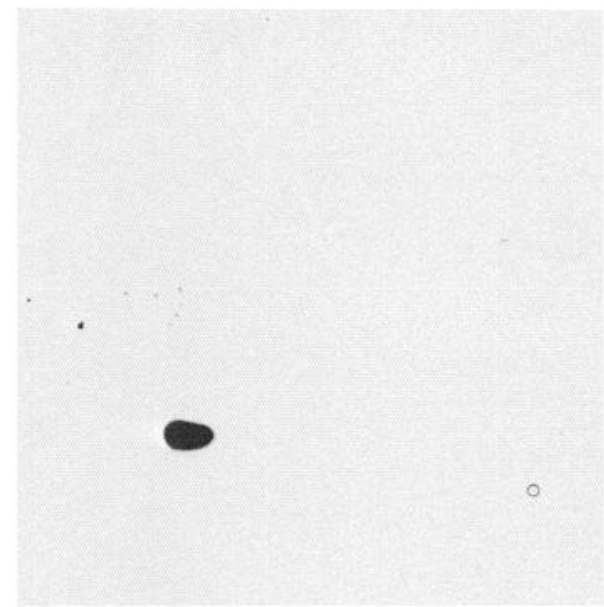

BOVINE ARPP-21
B.

ARPP-21A

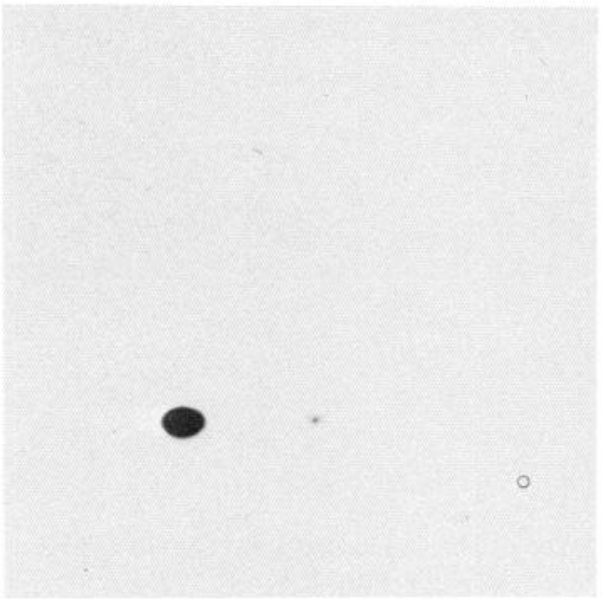

ARPP-21B

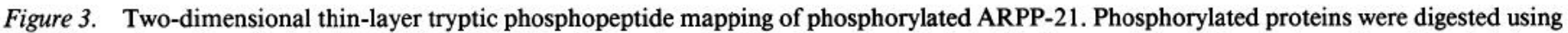

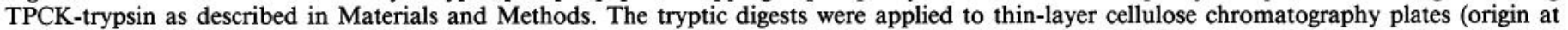

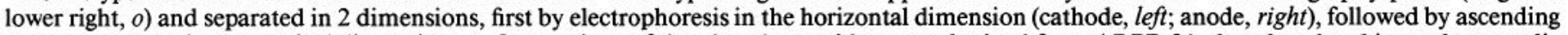

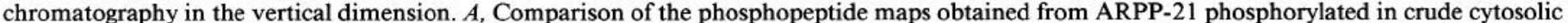

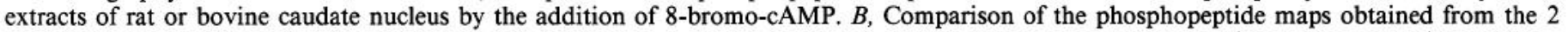

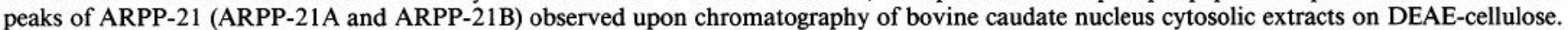
All 4 phosphopeptide maps appear virtually identical.

onto a column $(5 \times 50 \mathrm{~cm})$ of DEAE-cellulose $(\mathrm{DE}-52)$ previously equilibrated with buffer $B$. After washing the column with 1.5 liters of buffer $B$, the bound proteins were eluted at a flow rate of $4 \mathrm{ml} / \mathrm{min}$ with a 4 liter gradient of $0-0.5 \mathrm{M} \mathrm{NaCl}$ made up in buffer B. Two peaks of ARPP-21, which were present in approximately equal amounts, were detected and were pooled separately, as indicated in Figure 4. The first peak eluted at a conductivity of about $630 \mu \mathrm{S}$ and the second peak eluted at a conductivity of about $790 \mu \mathrm{S}$. Comparison of the $M_{r}=21,000$ phosphoproteins contained within each pool by 2-dimensional thin-layer phosphopeptide mapping of tryptic digests is shown in Figure $3 B$. The 2 phosphoproteins obtained from the DEAEcellulose column yielded identical phosphopeptide maps; these maps were also identical to those observed for ARPP-21 present in crude cytosolic extracts of rat or bovine caudate nucleus subjected to 8-bromo-cAMP-stimulated protein phosphorylation (Fig. $3 A$ ). This finding suggested that the 2 peaks of ARPP-21 observed represent closely related isoforms of a single phosphoprotein, which have been designated ARPP-21A and ARPP-21B. DARPP-32, a dopamine- and cAMP-regulated phosphoprotein with a distribution in brain similar to that of ARPP-21 (Hemmings et al., 1984b), eluted much later than ARPP-21 at a conductivity of about $1.25 \mathrm{mS}$ (Fig. 4).

Step 3: ammonium sulfate fractionation. In preliminary experiments, ARPP-21 was found to be soluble in solutions containing up to $45 \%$ saturated ammonium sulfate (data not shown). 


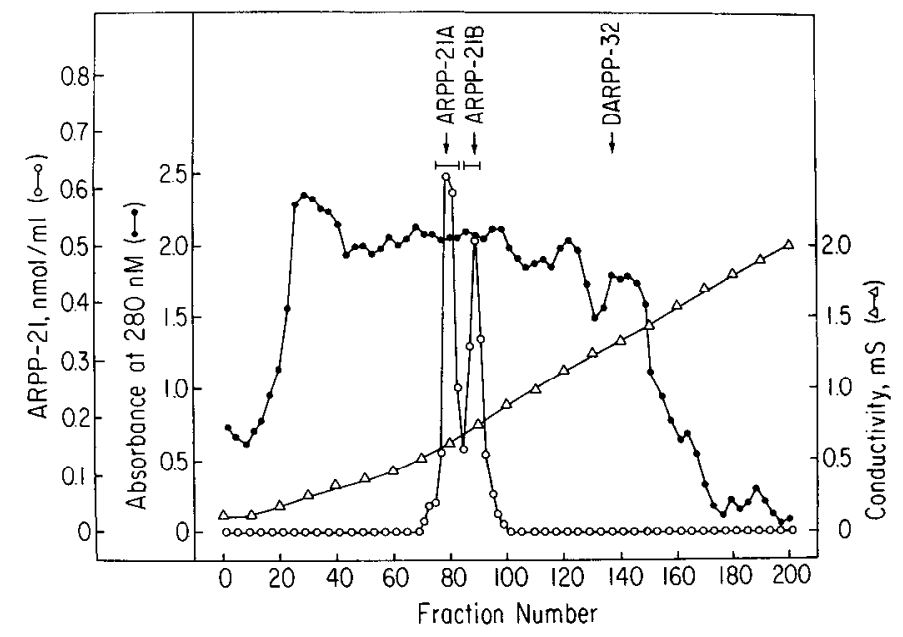

Figure 4. Chromatography of caudate nucleus cytosol on DEAE-cellulose (DE-52) at pH 8.0 (Step 2). The flow rate was $4 \mathrm{ml} / \mathrm{min}$, and 15.0 $\mathrm{ml}$ fractions were collected. Aliquots of each fraction were assayed for ARPP-21 by the phosphorylation assay described in Materials and Methods. The elution positions of ARPP-21A, ARPP-21B, and DARPP32 are indicated by arrows. The fractions of ARPP-21A and ARPP$21 \mathrm{~B}$ pooled for further purification are indicated by the horizontal bars.

The 2 pooled fractions of ARPP-21A and ARPP-21B obtained by chromatography on DEAE-cellulose were fractionated with ammonium sulfate by the slow addition of solid ammonium sulfate with stirring to a saturation (at $0^{\circ} \mathrm{C}$ ) of $45 \%(0.258 \mathrm{gm} /$ $\mathrm{ml}$ ). The solutions were stirred for $1 \mathrm{hr}$, and the precipitated proteins were removed by centrifugation at $27,000 \times g$ for 20 min using a GSA rotor.

Step 4: phenyl-sepharose CL-4B chromatography. The ammonium sulfate soluble proteins obtained from the 2 DEAEcellulose column pools (Step 3) were each loaded at a flow rate of $1.5 \mathrm{ml} / \mathrm{min}$ directly onto separate columns $(2.5 \times 10 \mathrm{~cm})$ of phenyl-Sepharose CL-4B previously equilibrated with buffer C. After washing each of the columns with $100 \mathrm{ml}$ of buffer $\mathrm{C}$, the bound proteins were eluted at a flow rate of $1.5 \mathrm{ml} / \mathrm{min}$ with $500 \mathrm{ml}$ gradients from buffer $\mathrm{C}$ to buffer D (Fig. 5). Aliquots of each fraction were dialyzed against buffer $A$ to remove ammonium sulfate and ethylene glycol prior to assay. The absorbance at $280 \mathrm{~nm}$ of the column fractions was not monitored due to interference from these solutes. Single peaks exhibiting slight tailing were obtained for both ARPP-21A and ARPP$21 \mathrm{~B}$; the tailing was more pronounced if ethylene glycol was not used in the gradients. Both $\Lambda$ RPP-21A and ARPP-21B eluted at a conductivity of about $6.0 \mathrm{mS}$. The peak fractions of ARPP$21 \mathrm{~A}$ and ARPP-21B were each pooled and dialyzed overnight against 3 changes of 4 liters of $10 \mathrm{mM} \mathrm{NH} \mathrm{NHCO}_{3}$. The dialyzed proteins were lyophilized and then solubilized in buffer $\mathrm{E}$.

Step 5: Mono $Q$ FPLC. ARPP-21A and ARPP-21B were further purified by anion-exchange FPLC using a Mono Q HR 16/10 column previously equilibrated with buffer E (Fig. 6). ARPP-21 was eluted at a flow rate of $3 \mathrm{ml} / \mathrm{min}$ with increasing gradients of $\mathrm{NaCl}$ in buffer $\mathrm{E}$; elution was monitored continuously at $280 \mathrm{~nm}$. Neither ARPP-21A nor ARPP-21B exhibited any absorbance at $280 \mathrm{~nm}$, which is consistent with their amino acid compositions (see below). ARPP-21A and ARPP-21B were clearly resolved by FPLC using the Mono $Q$ anion-exchange resin. ARPP-21A eluted at a concentration of $\mathrm{NaCl}$ of about $0.15 \mathrm{M}$, while ARPP-21B eluted at a concentration of $\mathrm{NaCl}$ of
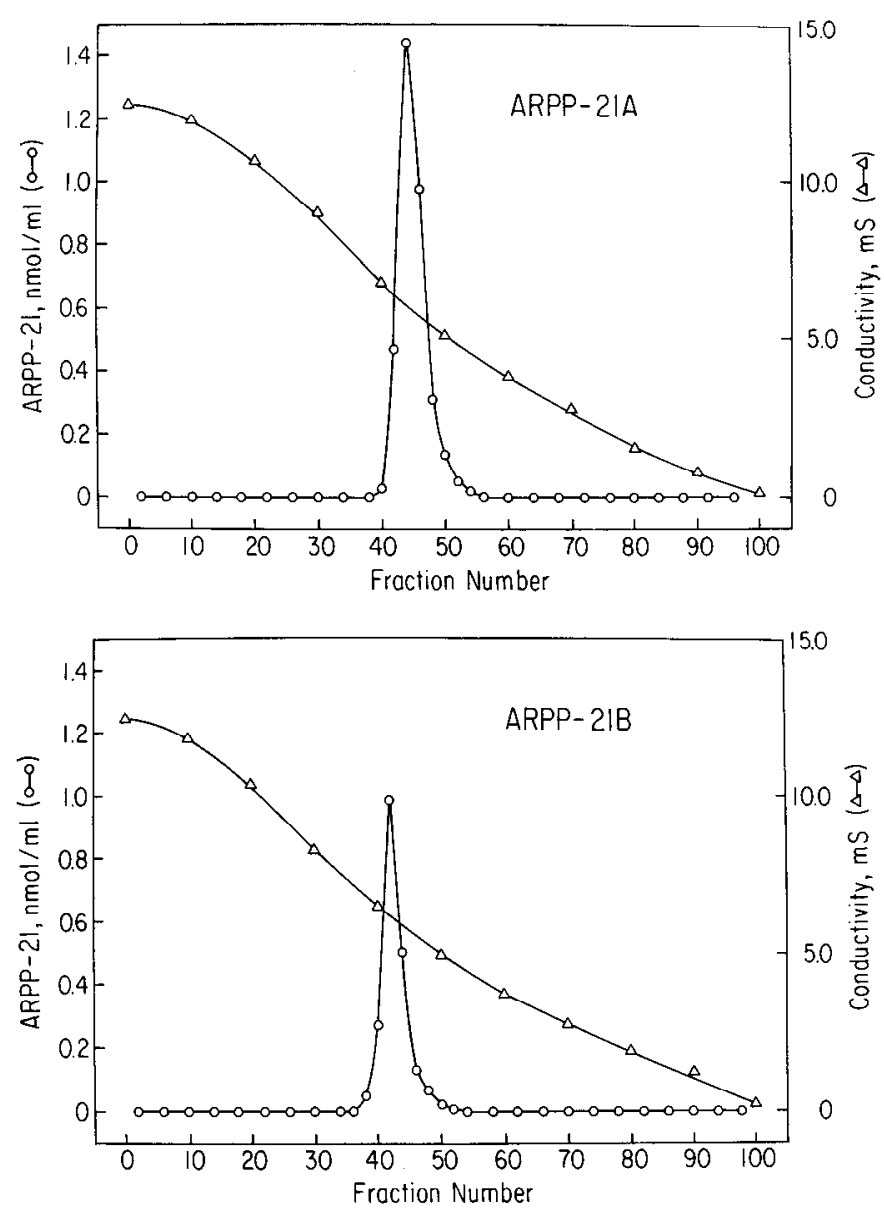

Figure 5. Chromatography of $45 \%$ saturated ammonium sulfate-soluble proteins on phenyl-Sepharose CL-4B at pH 8.0 (Step 4). The flow rate was $1.5 \mathrm{ml} / \mathrm{min}$, and $5.0 \mathrm{ml}$ fractions were collected. Aliquots of each fraction were dialyzed and assayed for ARPP-21 by the phosphorylation assay described in Materials and Methods. The chromatograms obtained for ARPP-21A (above) and ARPP-21B (below) are shown.

about $0.17 \mathrm{M}$. The ARPP-21A pool from the DEAE-cellulose column was contaminated with a small amount of ARPP-2 lB, while the ARPP-21B pool from the DEAE-cellulose column was contaminated with a small amount of ARPP-21 A. The peak fractions of ARPP-21A or ARPP-21B from each run were combined and dialyzed against 2 changes of 4 liters of $10 \mathrm{~mm}$ $\mathrm{NH}_{4} \mathrm{HCO}_{3}$. The dialyzed proteins were lyophilized and solubilized in $20 \mathrm{~mm}$ sodium HEPES (pH 7.4) containing $1 \mathrm{~mm}$ DTT and were stored at $-70^{\circ} \mathrm{C}$. Repeated freezing and thawing of ARPP-21 over a 6 month period resulted in the formation of higher-molecular-weight aggregates detected by SDS/PAGE that could not be reduced by high concentrations of 2-mercaptoethanol or DTT.

A summary of the purification procedure developed for ARPP21 is presented in Table 1. ARPP-21 was assayed using a phosphorylation assay employing $\gamma^{-32}$ P-ATP and the catalytic subunit of CAMP-dependent protein kinase. Interfering endogenous protein kinase and phosphoprotein phosphatase activity was eliminated by heating the samples prior to assay since control experiments revealed that ARPP- 21 is stable to heat treatment (data not shown). This assay appeared to be unreliable in assaying the $45 \%$ saturated ammonium sulfate supernatants, possibly because of the presence of an endogenous heat-stable pro- 

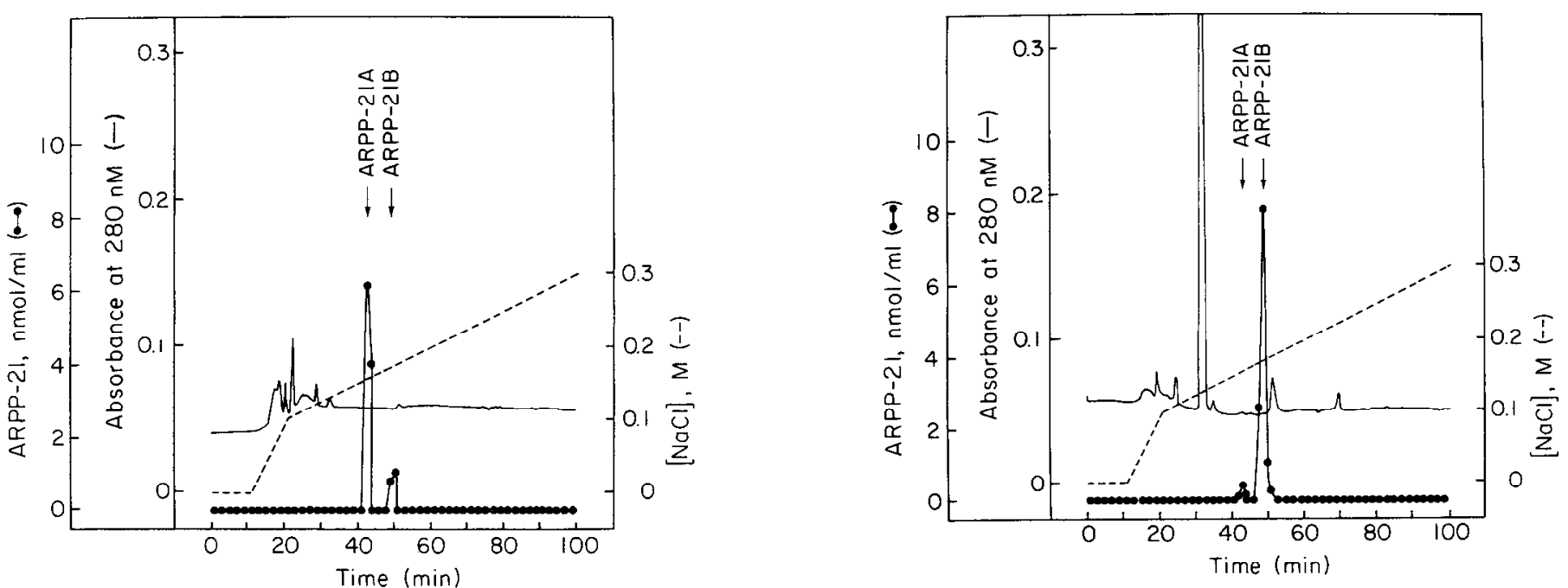

Figure 6. FPLC of Step 4 pools on a Mono Q 16/10 column at pH 7.5 (Step 5). The flow rate was $3 \mathrm{ml} / \mathrm{min}$, and $1 \mathrm{~min}$ fractions were collected. Aliquots of each fraction were assayed for ARPP-21 by the phosphorylation assay described in Materials and Methods. The elution positions of ARPP-21A and ARPP-21B are indicated by arrows. The chromatograms obtained for ARPP-21A (left) and ARPP-21B (right) are shown.

tein kinase inhibitor (see, for example, Walsh et al., 1971). About $0.7 \mathrm{mg}$ each of ARPP-21A and ARPP-21B were obtained with a final yield of about $20 \%$. ARPP-21 was purified 2610 -fold and ARPP-21B was purified 2940 -fold. This purification procedure has been carried out a total of 6 times, with no significant variation in the results.

Figure $7 \mathrm{~A}$ shows the protein staining pattern and Figure $7 \mathrm{~B}$ shows an autoradiogram of phosphorylated aliquots from each step of the purification procedure of ARPP-21A and ARPP21B analyzed by SDS/PAGE. Protein staining using either Coomassie brilliant blue R250 (Fig. $7 A$ ) or a silver staining technique (data not shown) of the purified preparations of both ARPP-21A and ARPP-21B (lane 4) yielded a single band of apparent $M_{r}=21,000$, suggesting homogeneity of the 2 preparations. Similarly, autoradiography indicated that all of the ${ }^{32} \mathrm{P}$-radioactivity comigrated with the protein staining bands. Purified ARPP-21A and ARPP-21B comigrated with the ARPP-21 detected by 8-bromo-cAMP-stimulated protein phosphorylation in crude rat or bovine caudate nucleus cytosolic extracts. The electrophoretic migration of ARPP-21A and ARPP-2 1 B upon SDS/PAGE were not detectably different. Twodimensional thin-layer phosphopeptide maps of purified ARPP-21A and ARPP-21B (data not shown) were identical to those of the ARPP-21A or ARPP-21B present in the DEAEcellulose column fractions and to endogenously phosphorylated ARPP-21 (Fig. 3).

\section{Characterization of purified bovine ARPP-21}

Comparison of $A R P P-21 A$ and $A R P P-2 I B$ by $H P L C$ peptide mapping. The purified preparations of ARPP-21A and ARPP$21 \mathrm{~B}$ wcre comparcd using analytical HPLC peptide mapping of tryptic digests (Fig. 8) by the methods described by Hemmings et al. (1984d) and Williams et al. (1986). Although the overall elution profiles of the tryptic peptides derived from ARPP-21A and ARPP-21B were very similar, there were several clear differences in the peptides eluting later in the chromatograms (after $70 \mathrm{~min}$ ). These differences did not appear to be due to variation in the enzymatic digests since they were reproducible. There were no significant differences between the HPLC tryptic peptide maps of phosphorylated and dephosphorylated ARPP-21B (data not shown).

Amino acid analyses. The amino acid compositions of purified ARPP-21A and ARPP-21B are shown in Table 2. The compositions of the 2 forms of ARPP- 21 are not significantly different given the errors of about $10 \%$ in these determinations. The compositions are remarkable for the absence of methionine, tyrosine, phenylalanine, histidine, and tryptophan. The absence of any aromatic amino acids accounts for the very low absorbance of ARPP-21 at $280 \mathrm{~nm}$. There is a very high content of glutamic acid/glutamine, which accounts for $25 \mathrm{~mol} \%$ of the amino acids in ARPP-21, which is consistent with the acidic isoelectric point of ARPP-21 (Fig. 2). The partial specific volume of ARPP-21 calculated from its amino acid composition using values from Cohn and Edsall (1943) is $0.718 \mathrm{ml} / \mathrm{gm}$.

Stability to denaturation. ARPP-21 is heat stable. Heating of crude or purified ARPP-21 to $95^{\circ} \mathrm{C}$ for $5 \mathrm{~min}$ did not reduce the ability of ARPP-21 to be phosphorylated by exogenous cAMP-dependent protein kinase at the same site, nor was the purified protein precipitated. In addition, ARPP-21 in crude cytosol was soluble in solutions containing up to at least $50 \%$ (vol/vol) ethanol. However, ARPP-21 was only partially soluble at $\mathrm{pH} 2$ (data not shown).

Hydrodynamic measurements. The Stokes radius of purified ARPP-21 was determined by gel filtration on Ultrogel AcA 44 (LKB) by the method of Laurent and Killander (1964) as described previously (Hemmings et al., 1984b). The Stokes radius of both ARPP-21A and ARPP-21B was $26.3 \pm 1.1 \AA$. For a typical globular protein, this Stokes radius corresponds to a molecular mass of $30,500 \mathrm{Da}$.

The sedimentation coefficient of purified ARPP-21 was determined by velocity sedimentation using linear sucrose density gradients by the method of Martin and Ames (1961) as described previously (Hemmings et al., 1984b). The sedimentation coefficient of both ARPP-21A and ARPP-21B was $1.3 \pm 0.2 \mathrm{~S}$.

The molecular mass of ARPP-21 was calculated as described by Siegel and Monty (1966) using values of $26.3 \AA$ for the Stokes radius, $1.3 \mathrm{~S}$ for the sedimentation coefficient, and $0.718 \mathrm{ml} /$ gm (calculated from the amino acid composition) for the partial 


\section{A. Protein Stain}
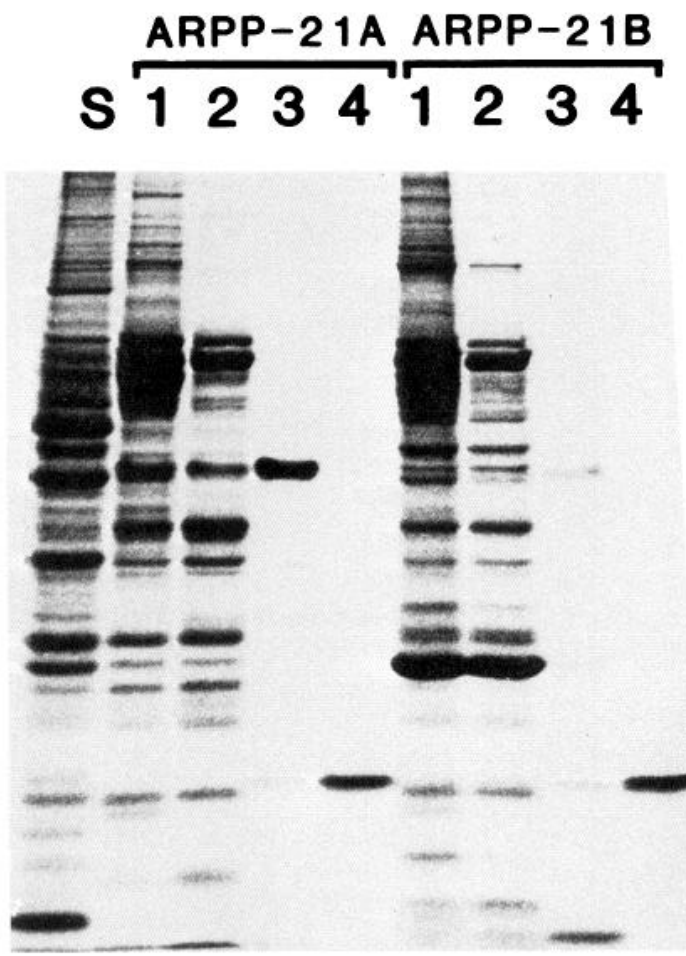

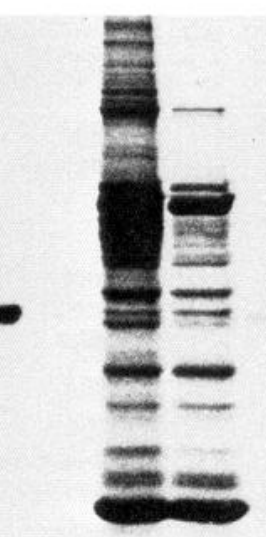

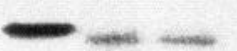

$\sin$

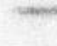

(4)

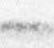

neven

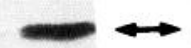

Figure 7. Purification of ARPP-21 monitored by SDS/PAGE. Coomassie brilliant blue R250 protein staining pattern $(A)$ and autoradiogram ( $B$ ) of the dried gel are shown. Samples were heated in a boiling water bath for 2 min to inactivate endogenous protein kinases and phosphoprotein phosphatases and were then assayed with exogenous catalytic subunit of cAMP-dependent protein kinase as described in Materials and Methods. The lane containing the starting material (Step 1) is indicated by $S$ and contained $50 \mu \mathrm{g}$ of protein. Aliquots from the various stages in the purification of ARPP-21A and ARPP-21B are 1, $40 \mu \mathrm{g}$ of DEAE-cellulose column pool (Step 2); 2, $35 \mu \mathrm{g}$ of ammonium sulfate-soluble fraction (Step 3); 3, 4 $\mu \mathrm{g}$ of phenyl-Sepharose CL-4B column pool (Step 4); and 4, $3 \mu \mathrm{g}$ of Mono Q HR 16/10 column pool (Step 5). ARPP-21 is indicated by the doubleheaded arrow. Protein values were determined by the method of Peterson (1977).

specific volume. A value of $13,700 \pm 1000 \mathrm{Da}$ was obtained, which is $65 \%$ of the apparent $M_{r}$ determined by SDS/PAGE (see above). The frictional ratio calculated from the hydrodynamic properties of ARPP-21 according to equation 2 of Siegel and Monty (1966) was 1.7 , indicative of an elongated tertiary structure.

Stoichiometry of phosphorylation. The stoichiometry of phosphorylation of purified ARPP-21A and ARPP-21B catalyzed by cAMP-dependent protein kinase was measured using a reaction mixture containing $2 \mu \mathrm{M}$ ARPP-21A or ARPP-21B (as determined by amino acid analysis), $8 \mu \mathrm{g} / \mathrm{ml}$ of the catalytic subunit of cAMP-dependent protein kinase, and $200 \mu \mathrm{M} \gamma-{ }^{32} \mathrm{P}$ ATP. A stoichiometry of $1.2 \pm 0.1 \mathrm{~mol}$ phosphate $/ \mathrm{mol}$ phosphoprotein was determined for both ARPP-21A and ARPP$21 \mathrm{~B}$ after a $60 \mathrm{~min}$ incubation (data not shown), based on a molecular mass of 13,700 Da. Longer incubation times did not result in any significant increase in the amount of phosphate incorporated.

Phosphoamino acid analysis. In order to determine the amino acid(s) in ARPP-21 phosphorylated by cAMP-dependent protein kinase, ${ }^{32} \mathrm{P}$-phospho-ARPP-21A and ${ }^{32} \mathrm{P}$-phospho-ARPP$21 \mathrm{~B}$ were proteolyzed with trypsin in gel pieces as described above, and the digests were subjected to partial acid hydrolysis (Bylund and Huang, 1976). The hydrolysates were analyzed for ${ }^{32} \mathrm{P}$-phosphoamino acids by thin-layer electrophoresis. As shown in Figure 9, phosphorylation of both ARPP-21A and ARPP21B occurred exclusively on seryl residues. Likewise, phosphorylation of ARPP-21 by 8-bromo-cAMP-stimulated endogenous protein kinase in crude extracts occurred only on seryl residues.

Protein kinase specificity of $A R P P-21$. A purified preparation of ARPP-21, containing both ARPP-21A and ARPP-21B, was tested as a substrate for a variety of purified protein kinase preparations. ARPP-21 was not phosphorylated by calcium/ calmodulin-dependent protein kinase I, protein kinase $\mathrm{C}$, or casein kinase II. ARPP-21 was phosphorylated poorly by calcium/calmodulin-dependent protein kinase II, at a rate $<5 \%$ of that observed for synapsin I (Ueda and Greengard, 1977), an excellent substrate for this enzyme (Nairn and Greengard, 1987). Similarly, ARPP-21 was phosphorylated poorly by cGMPdependent protein kinase at a rate $<10 \%$ of that observed for DARPP-32, a good substrate for this enzyme (Hemmings et al., 1984c). However, ARPP-21 was an excellent substrate for the catalytic subunit of cAMP-dependent protein kinase compared with DARPP-32 and synapsin I, 2 well-characterized neuronal substrates for cAMP-dependent protein kinase. The rates of phosphorylation observed at a substrate concentration of 1.5 $\mu \mathrm{M}$ for each protein were $1.6 \mu \mathrm{mol} / \mathrm{min} / \mathrm{mg}$ for ARPP-21, 1.0 $\mu \mathrm{mol} / \mathrm{min} / \mathrm{mg}$ for DARPP-32, and $2.6 \mu \mathrm{mol} / \mathrm{min} / \mathrm{mg}$ for synapsin I.

Protein phosphatase specificity of ARPP-21. The dephos- 


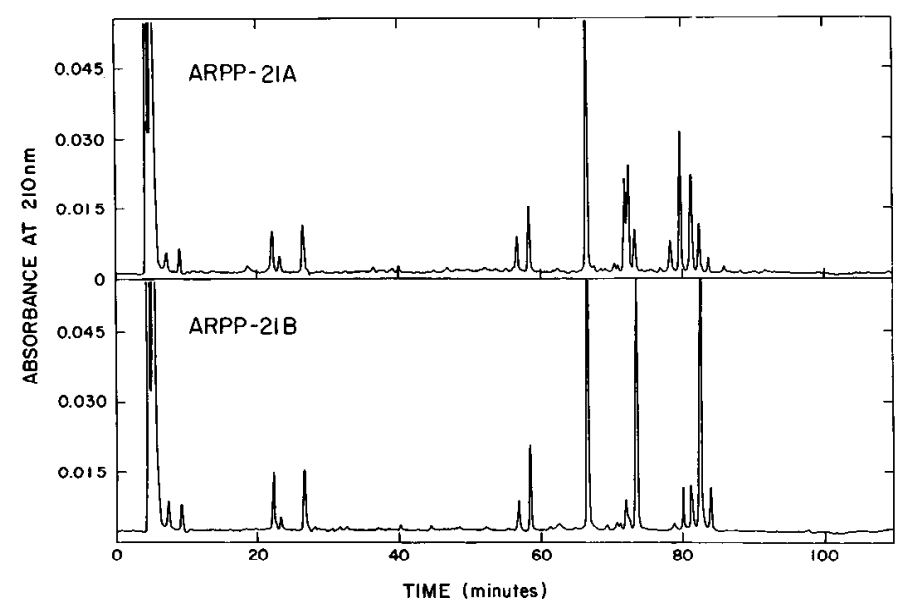

Figure 8. Analytical HPLC peptide mapping of tryptic peptides from 760 pmol of reduced and S- ${ }^{-14} \mathrm{C}$-carboxymethylated dephospho-ARPP$21 \mathrm{~A}$ (above) or dephospho-ARPP-21B (below). A Vydak C-4 column was eluted at a flow rate of $0.7 \mathrm{ml} / \mathrm{min}$ as described in Materials and Methods, and the absorbance of the effluent was monitored at $210 \mathrm{~nm}$.

phorylation of phospho-ARPP-21 by various purified protein phosphatasc preparations was compared with the dephosphorylation of the standard phosphoprotein substrate phosphorylase kinase as described previously (Hemmings et al., 1984a). Protein phosphatase-1 and -2A dephosphorylated phospho-ARPP-21 at 12 and $22 \%$, respectively, of the rate at which they dephosphorylated phosphorylase kinase, while protein phosphatase-2B and $-2 \mathrm{C}$ each dephosphorylated phospho-ARPP- 21 at $<2 \%$ of the rate at which they dephosphorylated phosphorylase kinase.

A summary of the physical and chemical properties of ARPP21 is presented in Table 3 . Since the only detectable differences between ARPP-21A and ARPP-21B were their elution positions from DEAE-cellulose and Mono Q and their HPLC tryptic peptide maps, the values listed in Table 3 for ARPP-21 apply to both ARPP-21A and ARPP-21B.

Characterization of anti-ARPP-21 antibodies. The specificity
Table 2. Amino acid compositions of ARPP-21A and ARPP-21B

\begin{tabular}{|c|c|c|c|c|}
\hline \multicolumn{3}{|c|}{ ARPP-21A } & \multicolumn{2}{|c|}{ ARPP-21B } \\
\hline $\begin{array}{l}\text { Amino } \\
\text { acid }\end{array}$ & Mol \% & $\begin{array}{l}\text { Residues/ } \\
\text { mol }^{a}\end{array}$ & Mol \% & $\begin{array}{l}\text { Residues/ } \\
\text { mol }^{a}\end{array}$ \\
\hline Cys $^{b}$ & 0.78 & 1.0 & 0.62 & 0.8 \\
\hline Asx & 6.3 & 8.1 & 5.9 & 7.6 \\
\hline Thr & 5.5 & 7.0 & 5.4 & 7.0 \\
\hline Ser ${ }^{c}$ & 9.8 & 12.5 & 10.0 & 12.9 \\
\hline Glx & 25.0 & 32.0 & 25.7 & 33.3 \\
\hline Pro & 5.1 & 6.5 & 4.9 & 6.3 \\
\hline Gly & 9.8 & 12.5 & 10.4 & 13.5 \\
\hline Ala & 6.7 & 8.6 & 6.4 & 8.3 \\
\hline Val & 4.4 & 5.6 & 4.2 & 5.4 \\
\hline Met & 0 & 0 & 0 & 0 \\
\hline Ile & 1.9 & 2.4 & 1.8 & 2.3 \\
\hline Leu & 9.9 & 12.7 & 10.3 & 13.3 \\
\hline Tyr & 0 & 0 & 0 & 0 \\
\hline Phe & 0 & 0 & 0 & 0 \\
\hline His & 0 & 0 & 0 & 0 \\
\hline Lys & 7.1 & 9.1 & 6.9 & 8.9 \\
\hline Arg & 7.8 & 10.0 & 7.6 & 9.9 \\
\hline $\operatorname{Trp}^{d}$ & 0 & 0 & 0 & 0 \\
\hline Total & & 128.0 & & 129.5 \\
\hline
\end{tabular}

Hydrolyses were carried out for 24,48 , and $72 \mathrm{hr}$ at $115^{\circ} \mathrm{C}$ in $6 \mathrm{~N} \mathrm{HCl}$ containing $0.02 \%(\mathrm{wt} / \mathrm{vol})$ phenol.

${ }^{a}$ The number of amino acid residues was calculated assuming a molecular weight of 13,700 calculated from hydrodynamic measurements (see Results).

${ }^{b}$ Determined as cysteic acid after performic acid oxidation (Moore, 1963).

- Obtained by extrapolation to zero time.

${ }^{a}$ Determined spectrophotometrically (Goodwin and Morton, 1946). Since the absorbance of ARPP-21 $(0.8 \mathrm{mg} / \mathrm{ml})$ at $280 \mathrm{~nm}$ was $<0.05 \mathrm{AU}$, it is concluded that the protein is devoid of tryptophan.

of antibodies to ARPP-21 could not be adequately analyzed by conventional methods of immunolabeling electrophoretic transfers of SDS-polyacrylamide gels to nitrocellulose membranes, since ARPP-21 failed to bind efficiently to nitrocellulose (of 0.1 ,

Table 1. Purification of ARPP-21 from $500 \mathrm{gm}$ of bovine caudate nucleus

\begin{tabular}{|c|c|c|c|c|c|c|}
\hline Step & $\begin{array}{l}\text { Volume } \\
(\mathrm{ml})\end{array}$ & $\begin{array}{l}\text { Protein }^{a} \\
(\mathrm{mg})\end{array}$ & $\begin{array}{l}\text { ARPP-21 } \\
\text { (nmol) }\end{array}$ & $\begin{array}{l}\text { Specific } \\
\text { activity } \\
\text { (nmol/mg) }\end{array}$ & $\begin{array}{l}\text { Purification } \\
\text { (fold) }\end{array}$ & $\begin{array}{l}\text { Yield }^{c} \\
(\%)\end{array}$ \\
\hline $\begin{array}{l}\text { 1. } 27,000 \times g \text { supernatant } \\
\text { ARPP-21 A }\end{array}$ & 2500 & 9625 & 346 & 0.036 & 1 & 100 \\
\hline 2A. DEAE-cellulose chromatography & 142 & 397 & 87 & 0.22 & 12.2 & 50 \\
\hline 3A. Ammonium sulfate fractionation & 155 & 108 & $(13)^{d}$ & $(0.12)$ & $(6.6)$ & $(7.5)$ \\
\hline 4A. Phenyl-Sepharose 4B chromatography & 80 & 5.8 & 40 & 6.9 & 383 & 23 \\
\hline 2B. DEAE-cellulose chromatography & 172 & 413 & 95 & 0.23 & 12.8 & 55 \\
\hline 3B. Ammonium sulfate fractionation & 190 & 122 & $(45)^{d}$ & $(0.37)$ & $(20)$ & (26) \\
\hline 4B. Phenyl-Sepharose 4B chromatography & 98 & 6.8 & 58 & 8.5 & 472 & 34 \\
\hline 5B. Mono Q HR 16/10 FPLC & 9 & 0.67 & 36 & 53 & 2940 & 21 \\
\hline
\end{tabular}

a Determined by the method of Lowry et al. as modified by Peterson (1977). Protein values for purified ARPP-21A or ARPP-21B determined by Bradford's method (1976) were $75-80 \%$ lower when BSA was used as a standard.

${ }^{b}$ Determined by a phosphorylation assay using $\gamma^{-32}$ P-ATP and the catalytic subunit of cAMP-dependent protein kinase as described in Materials and Methods. A phosphorylation stoichiometry of $1.0 \mathrm{~mol}$ phosphate/mol ARPP-21 is assumed.

c Calculated assuming that the amount of ARPP-21 measured in the supernatant consisted of 50\% ARPP-21A and 50\% ARPP-21B.

d The values determined for the amount of ARPP-21A and ARPP-21B in the ammonium sulfate supernatants using the phosphorylation assay proved to be unreliable, possibly due to the presence of an endogenous. protein kinase inhibitor (see text). 


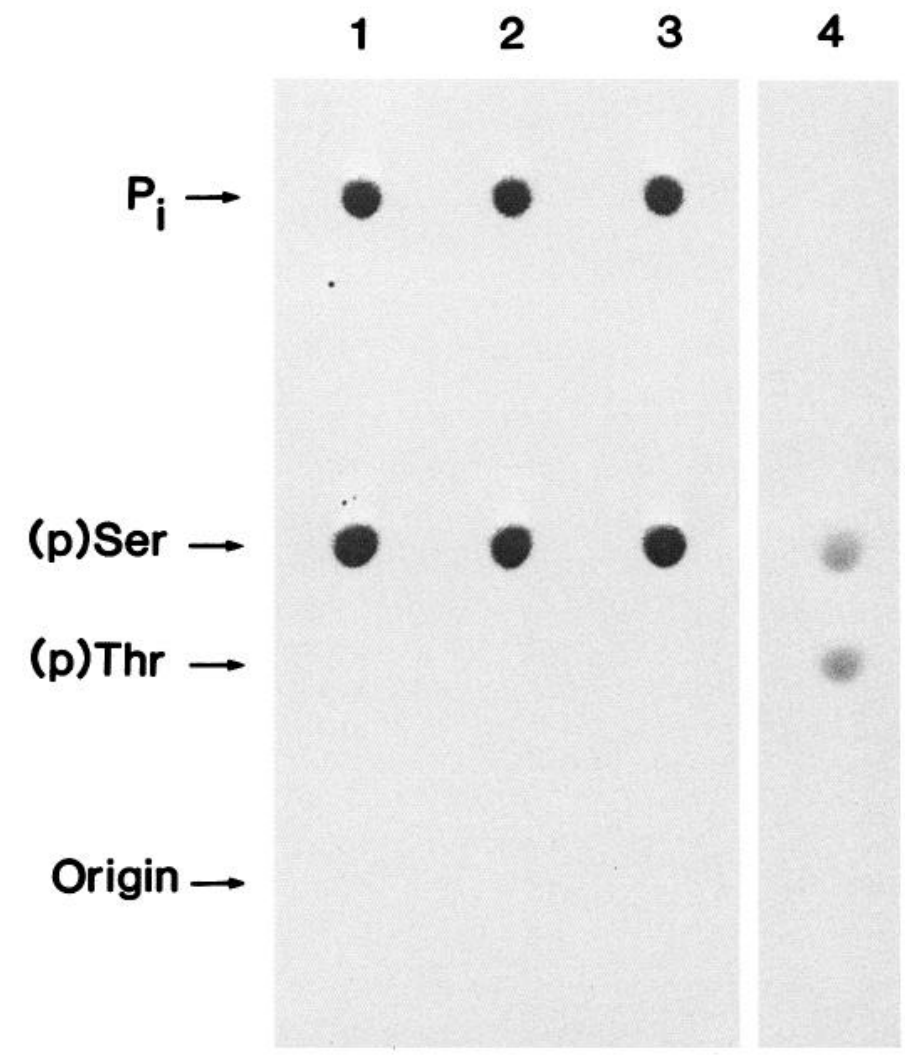

Figure 9. Identification of the phosphorylated amino acids in ${ }^{32} \mathrm{P}$ phospho-ARPP-21 by thin-layer electrophoresis. Electrophoresis was carried out in the vertical dimension with the anode above and the cathode below. Lane 1, Autoradiogram of purified ARPP-21 phosphorylated by the addition of 8-bromo-cAMP to bovine caudate nucleus cytosol; lane 2, autoradiogram of purified ARPP-21A phosphorylated by the purified catalytic subunit of CAMP-dependent protein kinase; lane 3, autoradiogram of purified ARPP-21B phosphorylated by the purified catalytic subunit of cAMP-dependent protein kinase; and lane 4 , ninhydrin stain of internal phosphoamino acid markers. $P_{i}$, inorganic ${ }^{32} \mathrm{P}$-phosphate; (p)Ser, phosphoserine; (p)Thr, phosphothreonine.
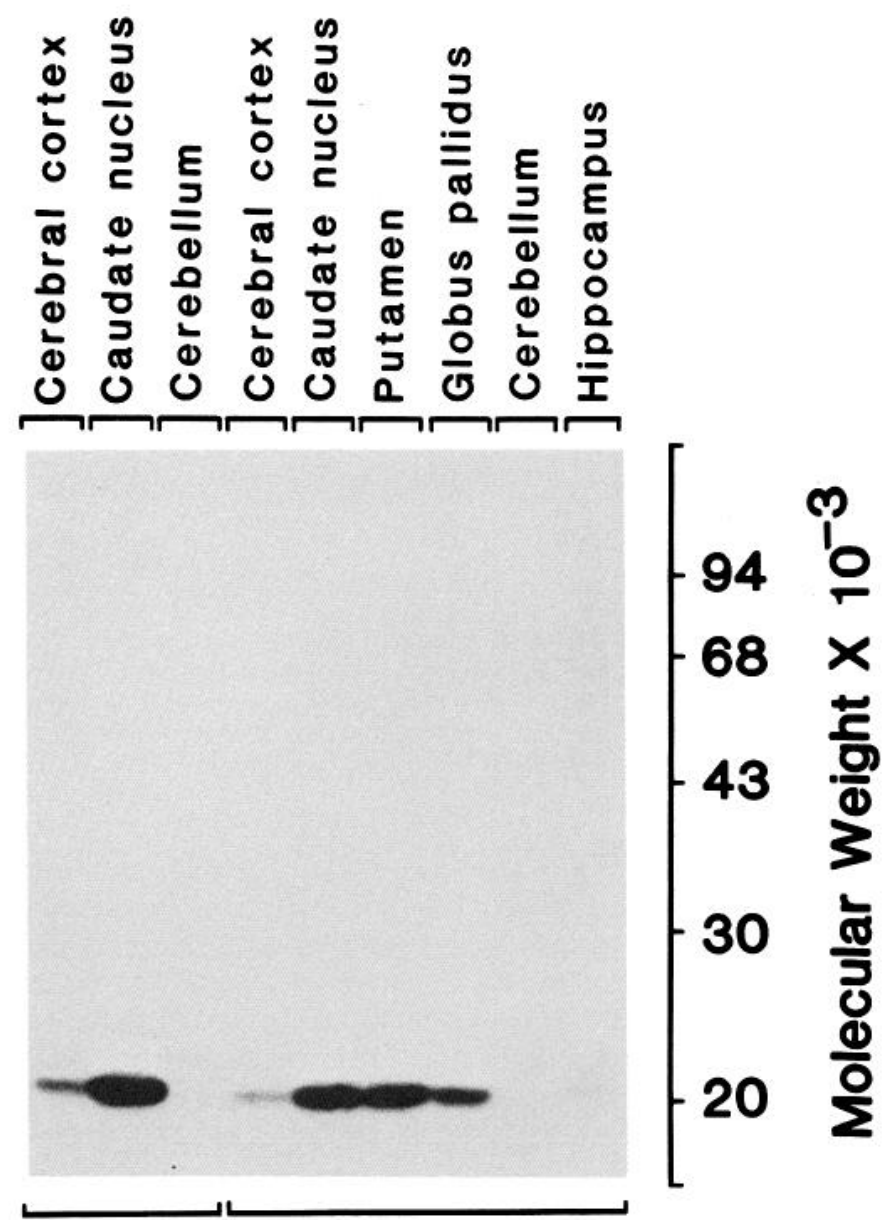

\section{Bovine Monkey}

Figure 10. Immunoprecipitation of ARPP-21 from phosphorylated extracts prepared from various regions of bovine and monkey brain. Crude cytosol was prepared from the brain regions indicated and phosphorylated using cAMP and $\gamma^{-32} \mathrm{P}$-ATP as described previously (Hemmings and Greengard, 1986). The phosphorylated proteins $(150 \mu \mathrm{g})$ were immunoprecipitated with $1 \mu \mathrm{l}$ each of monoclonal antibodies 21-3D and 21-6A. The immunoprecipitated proteins were then subjected to SDS/PAGE ( $11 \%$ acrylamide) and analyzed by autoradiography.

Table 3. Summary of physical and chemical properties of ARPP-21

\begin{tabular}{lll} 
Property & Method of determination & Value \\
\hline Molecular weight $\left(M_{r}\right)$ & SDS/PAGE & 21,000 \\
& Stokes radius and sedimentation coefficient ${ }^{a}$ & 13,700 \\
Isoelectric point $(\mathrm{pI})$ of & Polyacrylamide gel IEF & 4.6 \\
$\quad$ phospho-form & Gel filtration & $26.3 \AA$ \\
Stokes radius $(a)$ & Sucrose density gradient centrifugation & $1.3 \mathrm{~S}$ \\
Sedimentation coefficient $\left(\mathrm{s}_{20, w}\right)$ & Stokes radius and sedimentation coefficient & 1.7 \\
Frictional ratio $\left(f / f_{0}\right)^{b}$ & Stokes radius and sedimentation coefficient & 13.5 \\
Axial ratio & Amino acid analysis & High Glx; no Met, Tyr, \\
Amino acid composition & & Phe, His, Trp \\
& Amino acid analysis & $0.718 \mathrm{ml} / \mathrm{gm}$
\end{tabular}

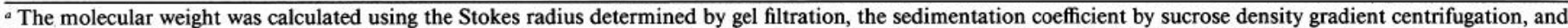

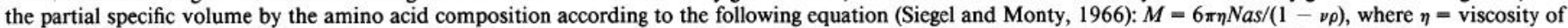
water at $20^{\circ} \mathrm{C}, N=$ Avogadro's number, $a=$ Stoke's radius, $s=$ sedimentation coefficient, $\nu=$ partial specific volume, and $\rho=$ density of water at $20^{\circ} \mathrm{C}$.

${ }^{b}$ The frictional ratio was calculated according to the following equation (Siegel and Monty, 1966): $f / f_{0}=\frac{a}{(3 v M / 4 \pi N)^{1 / 3}}$

c Value for a prolate ellipsoid (Schachman, 1959). 
0.2 , or $0.4 \mu \mathrm{m}$ pore sizc). The antibodies were analyzed for specificity by an immunoprecipitation assay using fixed Protein A-bearing Staphylococcus aureus cells (Pansorbin, CalbiochemBehring) as an immunoadsorbent as described previously for DARPP-32 (Hemmings and Greengard, 1986). Using cytosolic extracts of rat or bovine caudate nucleus phosphorylated by the addition of $\gamma-{ }^{32}$ P-ATP and 8-bromo-cAMP (Hemmings and Greengard, 1986), the rabbit antisera and mouse monoclonal antibodies 21-1A, 21-4B, 21-7A, 21-7G, 21-7N, 21-14.1, 21$14.3,21-14.5$ were found to immunoprecipitate bovine ARPP21 efficiently but not rat ARPP-21. Mouse monoclonal antibodies 21-3D and 21-6A were found to immunoprecipitate both rat and bovine ARPP-21, although rat ARPP-21 was immunoprecipitated less efficiently than bovine. No other immunoprecipitated proteins were detected in phosphorylated rat or bovine brain cytosol. All of the antibodies produced were able to react equally well with both purified isoforms of bovine $\Lambda R P P$ 21 (A and B) (data not shown).

The use of monoclonal antibodies 21-3D and 21-6A to immunoprecipitate ARPP-21 from various regions of bovine and monkey brain is shown in Figure 10. ARPP-21 was highly enriched in the basal ganglia, including the caudate nucleus, putamen, and globus pallidus. The amount of ARPP-21 present in the cerebral cortex was about $15 \%$ of that present in the caudate nucleus, as determined by liquid scintillation counting of the immunoprecipitated phosphoproteins (data not shown). ARPP-21 was undetectable in the cerebellum and was present at a very low concentration in the hippocampus.

\section{Discussion}

The purification and characterization of neurotransmitter-regulated neuronal phosphoproteins and the elucidation of their physiological roles provides an approach to determining the molecular mechanisms by which neurons respond to extracellular signals. Recent work has resulted in the identification in rat brain of a subset of substrates for cAMP-dependent protein kinase that are enriched in the forebrain basal ganglia (for review, see Hemmings et al., 1987b), brain regions that are densely inncrvated by mescncephalic dopamincrgic ncurons. The association of these cAMP-regulated phosphoproteins with the basal ganglia suggests that they may be involved in mediating certain of the physiological effects of dopamine acting through the D-1 dopamine receptor, a receptor subtype coupled to the stimulation of adenylate cyclase (Kebabian and Calne, 1979; Stoof and Kebabian, 1984). The phosphorylation of one of these phosphoproteins (DARPP-32) has been shown previously to be regulated by dopamine or by 8-bromo-cAMP in intact neurons (Walaas et al., 1983a; Walaas and Greengard, 1984; for review, see Walaas et al., 1986). This paper describes the purification to homogeneity and biochemical characterization of ARPP-21, a phosphoprotein that, like DARPP-32, is highly enriched in the basal ganglia and is regulated by cAMP in intact neurons.

In preliminary experiments, the cAMP analog 8-bromo-cAMP was found to stimulate the phosphorylation of a phosphoprotein of $M_{r}=21,000$ in crude cytosol prepared from bovine caudate nucleus; this phosphoprotein was found by 2-dimensional thinlayer phosphopeptide mapping studies to be identical to ARPP21 , a phosphoprotein of $M_{r}=21,000$ that had been identified previously in rat caudatoputamen as being highly concentrated in dopamine-innervated brain regions (Walaas et al., 1983c) and that has recently been shown to be regulated by cAMP in intact ncurons (Girault ct al., 1987, 1988; Shalaby ct al., 1987). In the present study, ARPP-21 was found to be highly enriched in caudate nucleus cytosol compared with cytosol from several other brain regions in bovine and monkey brain, results similar to those obtained previously in the rat. ARPP-21 was purified to homogeneity from bovine caudate nucleus cytosol and biochemically characterized.

Fractionation of bovine caudate nucleus cytosol on DEAEcellulose revealed the existence of 2 separate peaks of ARPP21 , termed ARPP-21A and ARPP-21B. These 2 peaks contained approximately equal amounts of ARPP-21, and were purified separately. The 2 peaks of ARPP- 21 obtained by DEAEcellulose chromatography can be combined and copurified through subsequent steps, and reseparated by FPLC using a Mono Q column as a final step (J.-A. Girault, H. C. Hemmings, Jr., and P. Greengard, unpublished observations), although this procedure results in a considerable decrease in the purity of ARPP-21B obtained.

The purification procedures described for ARPP-21A and ARPP-21B did not involve any potentially denaturing techniques and could be carried out in $6 \mathrm{~d}$. The use of FPLC proved to be a particularly useful method for achieving the final purification of ARPP-21A and ARPP-21B. Using the techniques described above, ARPP-21A has been purified 2610-fold to apparent homogeneity with a $20 \%$ recovery, while ARPP-21B has been purified 2940-fold to apparent homogeneity with a $21 \%$ recovery. Based on these yields, ARPP-21A and ARPP$21 \mathrm{~B}$ comprise roughly $0.038 \%$ and $0.034 \%$, respectively, of the total cytosolic protein present in a bovine caudate nucleus extract. ARPP-21 (ARPP-21A and ARPP-21B) is about 3-fold less abundant than DARPP-32 in bovine caudate nucleus cytosol (Hemmings et al., 1984b). More accurate quantitation of ARPP-21 in crude tissue fractions must await the development of methods more sensitive than the phosphorylation assay, such as radioimmunoassay, a technique that has been used successfully to quantitate DARPP-32 in various tissues (Hemmings and Greengard, 1986).

The 2 peaks of ARPP-21 (A and B) detected initially by chromatography on DEAE-cellulose or Mono $Q$ were found to be identical by 2 -dimensional thin-layer phosphopeptide mapping. This finding indicated that whatever feature is responsible for the chromatographic differences between ARPP-21 A and ARPP$21 \mathrm{~B}$ is not evident in the electrophoretic mobilities of their tryptic phosphorylation site peptides, and therefore most probably exists in another region of the molecule. The biochemical relationship between ARPP-21A and ARPP-21B was further analyzed by HPLC peptide mapping of tryptic digests of the purified preparations of ARPP-21A and ARPP-21B. A comparison of their tryptic HPLC maps indicated a marked degree of similarity between these 2 proteins; however, several specific differences were observed in the tryptic peptides eluting later in the chromatograms. These results are consistent with minor structural differences between ARPP-21 A and ARPP-21B, possibly due to posttranslational modification or to genetic polymorphism and the presence of 2 different allelic forms of ARPP21. We conclude that ARPP-21 consists of 2 closely related isoforms (ARPP-21A and ARPP-21B), with identical $M_{r}$ values, hydrodynamic properties, isoelectric points, amino acid compositions, phosphorylated amino acid residues, and immunologic reactivity with polyclonal and monoclonal antibodies but with different chromatographic mobilities on DEAE-cellulose or Mono $\mathrm{Q}$ and slightly different HPLC tryptic peptide maps. 
The amino acid sequences of ARPP-21A and ARPP-21B are probably very similar, and we are currently addressing this question by determining these sequences.

ARPP-21 is a highly acidic phosphoprotein. The amino acid composition of ARPP-21 is notable for the high content of glutamic acid/glutamine $(25 \mathrm{~mol} \%)$ and for the absence of any tyrosine, phenylalanine, tryptophan, histidine, or methionine. cAMP-dependent protein kinase catalyzes the phosphorylation of ARPP-21 to a stoichiometry of approximately 1 mol phosphate/mol ARPP-21. The solubility and ability of ARPP-21 to be phosphorylated were stable to heat or ethanol treatment and partially stable to acid treatment, suggesting that native ARPP21 possesses little ordered tertiary structure. This possibility is further supported by studies of the hydrodynamic properties of ARPP-21. ARPP-21 exhibited a high frictional ratio, which is consistent with an elongated, asymmetric tertiary structure. Furthermore, the molecular weight of ARPP-21 calculated from the hydrodynamic measurements was considerably less than the relative molecular weight determined by SDS-PAGE. Anomalous migration in SDS-polyacrylamide gels has been described previously for proteins with relatively decreased binding of SDS and extended conformations (Tung and Knight, 1972), conditions that appear to hold for ARPP-21, a highly acidic protein with a very asymmetric tertiary structure.

The stability of ARPP-21 to denaturation and its hydrodynamic properties are reminiscent of several other acidic phosphoproteins that appear to function as intracellular regulatory proteins. Thus, DARPP-32 (Hemmings et al., 1984b), skeletal muscle protein phosphatase inhibitor-1 (Nimmo and Cohen, 1978), adipose tissue protein phosphatase inhibitor-1 (Nemenoff et al., 1983), protein phosphatase inhibitor-2 (Huang and Glinsmann, 1976a), and G-substrate (Aswad and Greengard, 1981) arc cach stable to heat and acid treatments, and possess asymmetric tertiary structures. DARPP-32 (Hemmings et al., 1984 a), protein phosphatase inhibitor-1, protein phosphatase inhibitor-2 (Huang and Glinsmann, 1976b), and G-substrate (A. C. Nairn, H. C. Hemmings, Jr., and P. Greengard, unpublished observations) are each capable of inhibiting specific protein phosphatases. However, neither phospho- nor dephospho-ARPP-21 was capable of inhibiting either protein phosphatase-1, -2A, -2B, or -2C (H. C. Hemmings, Jr., P. Cohen, and $P$. Greengard, unpublished observations). The acidic isoelectric point and high glutamic acid/glutamine residue content suggest that ARPP-21 may function as a $\mathrm{Ca}^{2+}$-binding protein, since clusters of acidic amino acid residues are characteristic of many such proteins (Klee and Vanaman, 1982). Preliminary experiments have failed to reveal any $\mathrm{Ca}^{2+}$-binding activity in ARPP-21 (unpublished observations). Determination of the complete amino acid sequence of ARPP-21 may provide important clues as to its biochemical functions, such as identifying a putative $\mathrm{Ca}^{2+}$-binding site or additional phosphorylation sites.

ARPP-21 appears to be a specific substrate for cAMP-dependent protein kinase, and phospho-ARPP-2l a substrate for protein phosphatase- 1 and $-2 \mathrm{~A}$. None of the other purified protein kinase preparations tested displayed significant activity toward ARPP-21. The observation that phospho-ARPP-21 is a substrate for protein phosphatase-1 suggests that the state of phosphorylation of ARPP-21 may be regulated indirectly by DARPP32 via its inhibition of protein phosphatase-1 (Hemmings et al., 1984a; see also Hemmings et al., 1987c) in medium-sized spiny neurons, which contain both ARPP-21 and DARPP-32 (see below). The efficiency with which ARPP-21 is phosphorylated in vitro by cAMP-dependent protein kinase is comparable to that observed for DARPP-32 or synapsin I, 2 neuronal phosphoproteins that have previously been shown to be regulated in intact cells by dopamine acting through cAMP (Nestler and Greengard, 1980; Tsou and Greengard, 1982; Walaas et al., 1983a; Walaas and Greengard, 1984).

The regional distribution of ARPP-21, as determined by a phosphorylation assay (Walaas et al., 1983c) and by phosphorylation and immunoprecipitation (this study), has been shown to be quite similar to that of DARPP-32 in its restriction primarily to dopamine-innervated brain regions. Furthermore, immunocytochemical studies employing specific antibodies to ARPP-21 indicate that ARPP-21 is contained within many of the same cell types as DARPP-32, including the medium-sized spiny neurons of the caudatoputamen (Ouimet et al., 1983, 1984, 1989). The phosphorylation of DARPP-32 has previously been found to be regulated by dopamine and cAMP in slices prepared from rat caudatoputamen (Walaas et al., 1983a; Walaas and Greengard, 1984), while the phosphorylation of ARPP21 has been found to be regulated by CAMP in slices and cultured cells prepared from rodent caudatoputamen (Girault et al., 1987, 1988; Shalaby et al., 1987). Taken together, these findings suggest that ARPP-21, which appears to be present in many of the same cells as DARPP-32, may also be regulated by dopamine acting through cAMP in these cells. Experiments to demonstrate the regulation of the state of phosphorylation of ARPP-21 in intact cells by dopamine or other neurotransmitters acting through cAMP are in progress. If the regulation of ARPP-21 by dopamine and/or another neurotransmitter can be demonstrated experimentally, ARPP-21 will join DARPP-32 as a prime candidate for an intracellular messenger involved in mediating some of the physiological effects of neurotransmitters acting through cAMP. Interestingly, the phosphorylation of ARPP-21 has recently been shown to be regulated by vasoactive intestinal peptide in cultured mouse striatal cells (Shalaby et al., 1987; Girault et al., 1988).

\section{References}

Albert, K. A., C.-S. Wu, A. C. Nairn, and P. Greengard (1984) Inhibition by calmodulin of calcium/phospholipid-dependent protein phosphorylation. Proc. Natl. Acad. Sci. USA 81: 3622-3625.

Aswad, D. W., and P. Greengard (1981) A specific substrate from rabbit cerebellum for guanosine $3^{\prime}, 5^{\prime}$-monophosphate-dependent protein kinase. I. Purification and characterization from rabbit cerebellum. J. Biol. Chem. 256: 3487-3493.

Björklund, A., and O. Lindvall (1984) Dopamine-containing systems in the CNS. In Handbook of Chemical Neuroanatomy, Vol. 2: Classical Transmitters in the CNS, Part I, A. Björklund and T. Hökfelt, eds., pp. 55-122, Elsevier, Amsterdam.

Bolton, A. E., and W. M. Hunter (1973) The labelling of proteins to high specific radioactivities by conjugation to a ${ }^{125}$ I-containing acylating agent. Biochem. J. 133: 529-538.

Boyson, S. J., P. McGonigle, and P. B. Molinoff (1986) Quantitative autoradiographic localization of the $D_{1}$ and $D_{2}$ subtypes of dopamine receptors in rat brain. J. Neurosci. 6: 3177-3188.

Bradford, M. M. (1976) A rapid and sensitive method for the quantitation of microgram quantities of protein utilizing the principle of protein-dye binding. Anal. Biochem. 72: 248-254.

Bylund, D. B., and T.-S. Huang (1976) Decomposition of phosphoserine and phosphothreonine during acid hydrolysis. Anal. Biochem. 73: $477-485$.

Cohn, E. S., and J. T. Edsall (1943) Density and apparent specific volume of proteins. In Proteins, Amino Acids, and Peptides as Ions and Dipolar Ions, E. S. Cohen and J. T. Edsall, eds., pp. 370-381, Rheinhold, New York.

Dawson, T. M., D. R. Gehlert, R. T. McCabe, A. Barnett and J. K. 
Wamsley (1986) $D_{1}$ dopamine receptors in the rat brain: A quantitative autoradiographic analysis. J. Neurosci. 6: 2352-2365.

Dubois, A., M. Savasta, O. Curet and B. Scatton (1986) Autoradiographic distrihution of the $D_{1}$ agonist $\left[{ }^{3} \mathrm{H}\right] \mathrm{SKF} 38393$, in the rat brain and spinal cord. Neuroscience 19: 125-137.

Girault, J.-A., A. Horiuchi, H. C. Hemmings, Jr., A. C. Nairn, and P. Greengard (1987) Basal ganglia-enriched low molecular weight phosphoproteins: Regulation by cAMP and regional distribution in the rat brain. Soc. Neurosci. Abstr. 13: 900.

Girault, J.-A., I. A. Shalaby, N. L. Rosen, and P. Greengard (1988) Regulation by cAMP and vasoactive intestinal peptide of phosphorylation of specific proteins in striatal cells in culture. Proc. Natl. Acad. Sci. U.S.A., 85: 7790-7794.

Goodwin, T. W., and R. A. Morton (1946) The spectrophotometric determination of tyrosine and tryptophan in proteins. Biochem. J. 40: 628-632.

Greengard, P. (1978) Phosphorylated proteins as physiological effectors. Science 199: 146-152.

Hathaway, G. M., and J. A. Traugh (1983) Casein kinase II. Methods Enzymol. 99: 317-331.

Hemmings, H. C., Jr., and P. Greengard (1986) DARPP-32, a dopamine- and adenosine $3^{\prime}: 5^{\prime}$-monophosphate-regulated phosphoprotein: Regional, tissue and phylogenetic distribution. J. Neurosci. 6: 1469-1481.

Hemmings, H. C., Jr., P. Greengard, H. Y. L. Tung, and P. Cohen (1984a) DARPP-32, a dopamine-regulated neuronal phosphoprotein, is a potent inhibitor of protein-phosphatase-1. Nature 310: 503505.

Hemmings, H. C., Jr., A. C. Nairn, D. W. Aswad, and P. Greengard (1984b) DARPP-32, a dopamine- and adenosine 3',5'-monophosphate-regulated phosphoprotein enriched in dopamine-innervated brain regions. II. Purification and characterization of the phosphoprotein from bovine caudate nucleus. J. Neurosci. 4: 99-1 10.

Hemmings, H. C., Jr., A. C. Nairn, and P. Greengard (1984c) DARPP32 , a dopamine- and adenosine $3^{\prime}, 5^{\prime}$-monophosphate-regulated neuronal phosphoprotein. II. Comparison of the kinetics of phosphorylation of DARPP-32 and phosphatase inhibitor-1. J. Biol. Chem. 259: 14486-14490.

Hemmings, H. C., Jr., K. R. Williams, W. H. Konigsberg, and P. Greengard (1984d) DARPP-32, a dopamine- and adenosine 3',5'-monophosphate-regulated neuronal phosphoprotein. I. Amino acid sequence around the phosphorylated threonine. J. Biol. Chem. 259: 14491-14497.

Hemmings, H. C., Jr., A. C. Nairn, and P. Greengard (1986a) Protein kinases and phosphoproteins in the nervous system. In Neuropeptides in Neurologic and Psychiatric Disease, J. B. Martin and J. Barchas, eds., pp. 47-69, Raven, New York.

Hemmings, H. C., Jr., C. C. Ouimet, and P. Greengard (1986b) Purification and characterization of ARPP-21, a substrate for cAMPdependent protein kinase enriched in dopamine-innervated brain regions. Soc. Neurosci. Abstr. 12: 1022.

Hemmings, H. C., Jr., E. J. Nestler, S. I. Walaas, C. C. Ouimet, and P. Greengard (1987a) Protein phosphorylation and neuronal function: DARPP-32, an illustrative example. In New Insights into Synaptic Function, G. M. Edelman, W. E. Gall, and W. M. Cowan, eds. pp. 213-240, Wiley, New York.

Hemmings, H. C., Jr., S. I. Walaas, C. C. Ouimet, and P. Greengard (1987b) Dopamine receptors: Regulation of protein phosphorylation. In Dopamine Receptors, I. Creese and C. M. Fraser, eds., pp. 115151. Liss, New York.

Hemmings, H. C., Jr., S. I. Walaas, C. C. Ouimet, and P. Greengard (1987c) Dopaminergic regulation of protein phosphorylation in the striatum: DARPP-32. Trends Neurosci. 10: 377-383.

Huang, F. L., and W. H. Glinsmann (1976a) Separation and characterization of two phosphorylase phosphatase inhibitors from rabbit skcletal musclc. Eur. J. Biochcm. 70: 419-426.

Huang, F. L., and W. Glinsmann (1976b) A second heat-stable protein inhibitor of phosphorylase phosphatase from rabbit muscle. FEBS Lett. 62: 326-329.

Kaczmarek, L. K., K. R. Jennings, R. Strumwasser, A. C. Nairn, U. Walter, F. D. Wilson, and P. Greengard (1980) Microinjection of catalytic subunit of cyclic AMP-dependent protein kinase enhances calcium action potentials of bag cell neurons in cell culture. Proc. Natl. Acad. Sci. USA 77: 7487-7491.

Kebabian, J. W., and D. B. Calne (1979) Multiple receptors for dopamine. Nature 277: 93-96.
Kebabian, J. W., G. L. Petzold, and P. Greengard (1972) Dopaminesensitive adenylate cyclase in the caudate nucleus of rat brain and its similarity to the "dopamine receptor." Proc. Natl. Acad. Sci. USA 69: 2145-2149

Klee, C. B., and T. C. Vanaman (1982) Calmodulin. Adv. Protein Chem. 35: 231-321.

Köhler, G., and C. Milstein (1975) Continuous culturcs of fused-cells secreting antibody of predefined specificity. Nature 256: 495-497.

Laemmli, U. K. (1970) Cleavage of structural proteins during the assembly of the head of bacteriophage T4. Nature 227:680-685.

Laurent, T. C., and J. Killander (1964) A theory of gel filtration and its experimental verification. J. Chromatogr. 14: 317-330.

Lindvall, O., and A. Björklund (1978) Organization of catecholamine neurons in the rat central nervous system. In Handbook of Psychopharmacology, Vol. 9, L. L. Iversen, S. D. Iversen, and S. H. Snyder, eds., pp. 139-231, Plenum, New York.

Lowry, O. H., N. J. Rosebrough, A. L. Farr, and R. J. Randall (1951) Protein measurement with the Folin phenol reagent. J. Biol. Chem. 193: 265-275.

Martin, R. G., and B. N. Ames (1961) A method for determining the sedimentation behavior of enzymcs: Application to protcin mixtures. J. Biol. Chem. 236: 235-237.

McGuinness, T. L., Y. Lai, and P. Greengard (1985) $\mathrm{Ca}^{2+} /$ calmodulindependent protein kinase II: Isozymic forms from rat forebrain and cerebellum. J. Biol. Chem. 260: 1696-1704.

Miller, R. J., and J. McDermed (1979) Dopamine-sensitive adenylate cyclase. In The Neurobiology of Dopamine, A. S. Horn, J. Korf, and B. H. C. Westerink, eds, pp. 159-177, Academic, London.

Moore, R. Y., and F. E. Bloom (1978) Central catecholamine neuron systems: Anatomy and physiology of the dopamine systems. Annu. Rev. Neurosci. 1: 129-169.

Moore, S. (1963) On the determination of cystine as cysteic acid. J. Biol. Chem. 238: 235-237.

Nairn, A. C., and P. Greengard (1987) Purification and characterization of calcium/calmodulin-dependent protein kinase I from bovine brain. J. Biol. Chem. 262: 7273-7281.

Nairn, A. C., H. C. Hemmings, Jr., and P. Greengard (1985) Protein kinases in the brain. Annu. Rev. Biochem. 54: 931-976.

Nemenoff, R. A., P. J. Blackshear, and J. Avruch (1983) Hormonal regulation of protein phosphorylation: Identification and hormonal regulation of protein phosphatase inhibitor-1 in rat adipose tissue. $J$. Biol. Chem. 258: 9437-9443.

Nestler, E. J., and P. Greengard (1980) Dopamine and depolarizing agents regulate the state of phosphorylation of protein I in the mammalian superior cervical sympathetic ganglion. Proc. Natl. Acad. Sci. USA 77: 7479-7483.

Nestler, E. J., and P. Greengard (1984) Protein Phosphorylation in the Nervous System, Wiley, New York.

Nimmo, G. A., and P. Cohen (1978) The regulation of glycogen mctabolism. Purification and characterization of protein phosphatase inhibitor-1 from rabbit skeletal muscle. Eur. J. Biochem. 87: 341351.

O'Farrell, P. Z., H. M. Goodman, and P. H. O'Farrell (1977) High resolution two-dimensional electrophoresis of basic as well as acidic proteins. Cell 12 : 1133-1142.

Ouimet, C. C., H. C. Hemmings, Jr., and P. Greengard (1983) Light and electron microscope immunocytochemistry of a dopamine- and cyclic AMP-regulated phosphoprotein (DARPP-32) in rat brain. Soc. Neurosci. Abstr. 9: 82.

Ouimet, C. C., P. E. Miller, H. C. Hemmings, Jr., S. I. Walaas, and P. Greengard (1984) DARPP-32, a dopamine- and adenosine 3',5' monophosphate-regulated phosphoprotein enriched in dopamine-innervated brain regions. III. Immunocytochemical localization. J. Neurosci. 4: 111-124.

Ouimet, C. C., H. C. Hemmings, Jr., and P. Greengard (1989) ARPP21 , a cyclic AMP-regulated phosphoprotein enriched in dopamineinnervated brain regions. II. Immunocytochemical localization in rat brain. J. Neurosci. 9: 863-873.

Peterson, G. L. (1977) A simplification of the protein assay of Lowry et al. which is more generally applicable. Anal. Biochem. 83: 346356

Savasta, M., A. Dubois, and B. Scatton (1986) Autoradiographic localization of $\mathrm{D}_{1}$ dopamine receptors in the rat brain with $\left[{ }^{3} \mathrm{H}\right] \mathrm{SCH}$ 23390. Brain Res. 375: 291-301.

Schachman, H. K. (1959) Ultracentrifugation in Biochemistry, p. 239 Academic, New York. 
Shalaby, I., J.-A. Girault, N. Rosen, and P. Greengard (1987) Regulation by CAMP and vasoactive intestinal peptide of the phosphorylation of three low molecular weight proteins in striatal cells in culture. Soc. Neurosci. Abstr. 13: 900.

Siegel, L. M., and K. J. Monty (1966) Determination of molecular weights and frictional ratios of proteins in impure systems by use of gel filtration and density gradient centrifugation. Application to crude preparations of sulfite and hydroxylamine reductases. Biochim. Biophys. Acta 112: 346-362.

Stoof, C. J., and J. W. Kebabian (1984) Two dopamine receptors: Biochemistry, physiology and pharmacology. Life. Sci. 35: 2281-2296.

Tsou, K., and P. Greengard (1982) Regulation of phosphorylation of Proteins $\mathrm{I}_{1} \mathrm{III}_{\mathrm{a}}$ and $\mathrm{III}_{\mathrm{b}}$ in rat neurohypophysis in vitro by electrical stimulation and neuroactive agents. Proc. Natl. Acad. Sci. USA 79: 6075-6079.

Tung, J.-S., and C. A. Knight (1972) Relative importance of some factors affecting the electrophoretic migration of proteins in sodium dodecyl sulfate-polyacrylamide gels. Anal. Biochem. 48: 153-163.

Ueda, T., and P. Greengard (1977) Adenosine 3':5'-monophosphateregulated phosphoprotein system of neuronal membranes. I. Solubilization, purification, and some properties of an endogenous phosphoprotein. J. Biol. Chem. 252: 5155-5163.

Walaas, S. I., and P. Greengard (1984) DARPP-32, a dopamine and adenosine $3^{\prime}: 5^{\prime}$-monophosphate regulated phosphoprotein enriched in dopamine-innervated brain regions. I. Regional and cellular distribution in the rat brain. J. Neurosci. 4: 84-98.

Walaas, S. I., D. W. Aswad, and P. Greengard (1983a) A dopamineand cyclic AMP-regulated phosphoprotein enriched in dopamineinnervated brain regions. Nature 301: 69-71.

Walaas, S. I., A. C. Nairn, and P. Greengard (1983b) Regional dis- tribution of calcium- and cyclic AMP-regulated protein phospherylation systems in mammalian brain. I. Particulate systems. J. Neurosci. 3: 291-301.

Walaas, S. I., A. C. Nairn, and P. Greengard (1983c) Regional distribution of calcium-and cyclic AMP-regulated protein phosphorylation systems in mammalian brain. II. Soluble systems. J. Neurosci. 3. 302-311.

Walaas, S. I., C. C. Ouimet, H. C. Hemmings, Jr., and P. Greengard (1986) DARPP-32, a dopamine-regulated neuronal phosphoprotein in the basal ganglia. In Dopaminergic Systems and Their Regulation, G. N. Woodruff, J. A. Poat, and P. J. Roberts, eds., pp. 165-179, Macmillan, London.

Walsh, D. A., C. D. Ashby, C. Gonzalez, D. Calkins, E. H. Fischer, and E. G. Krebs (1971) Purification and characterization of a protein inhibitor of adenosine $3^{\prime}: 5^{\prime}$-monophosphate-dependent protein kinases. J. Biol. Chem. 246: 1977-1985.

Walter, U., P. Miller, F. Wilson, D. Menkes, and P. Greengard (1980) Immunological distinction between guanosine $3^{\prime}: 5^{\prime}$-monophosphatedependent and adenosine $3^{\prime}: 5^{\prime}$-monophosphate-dependent protein kinases. J. Biol. Chem. 255: 3757-3762.

Whittaker, V. P., and L. A. Barker (1972) The subcellular fractionation of brain tissue with special reference to the preparation of synaptosomes and their component organelles. In Methods of Neurochemistry, R. Fried, ed., pp. 1-52, Marcel Dekker, New York.

Williams, K. R., H. C. Hemmings, Jr., M. B. LoPresti, W. H. Konigsberg, and P. Greengard (1986) DARPP-32, a dopamine- and cyclic AMP-regulated neuronal phosphoprotein: Primary structure and homology with protein phosphatase inhibitor-1. J. Biol. Chem. 261: 1890-1903. 